Volume 13, Issue 2 (Summer 2021)

\title{
Matter as an Artist: Rubens's Myths of Spontaneous Generation
}

\author{
Marisa Mandabach
}

Recommended Citation:

Marisa Mandabach, "Matter as an Artist: Rubens's Myths of Spontaneous Generation," Journal of Historians of Netherlandish Art 13:2 (Summer 2021)

DOI: $\underline{10.5092 / \text { jhna.13.2.3 }}$

Available at https://ihna.org/articles/matter-as-an-artist-rubenss-myths-of-spontaneousgeneration/

Published by Historians of Netherlandish Art: https://hnanews.org/ Republication Guidelines: https://jhna.org/republication-guidelines/

Note: This PDF is provided for reference purposes and does not contain all the functionality and features of the online publication. Illustrations follow the text. This PDF provides paragraph numbers as well as page numbers for citation purposes.

ISSN: 1949-9833 


\section{Matter as an Artist: Rubens's Myths of Spontaneous Generation}

Marisa Mandabach

Three works by Peter Paul Rubens (1577-1640) entail mythologized scenes of spontaneous generation, or the creation of species from nature's raw matter: Head of Medusa (ca. 1613-1618), The Discovery of Erichthonius (ca. 1616), and the oil sketch Deucalion and Pyrrha (ca. 1636). In these works Rubens naturalizes the life of painting within its materials, implying matter — paint, with its pigments and mediating liquids — as an intrinsic, animating quality of his images and even as a counterpart to or collaborator with the artist. This essay explores these ideas to show how Rubens's technical and artisanal understanding of painting and its materials could have informed his interpretation of ancient myths.

1 In his 1672 life of Peter Paul Rubens (1577-1640), published in Rome, Giovanni Pietro Bellori inserts six lines of Latin verse that he says were inscribed on Rubens's tomb in the church of Saint James in Antwerp and that conclude as follows:

"You, Rubens, give life and mind to your figures

And through you, light and shadow and color live.

What did death with its black funeral want with you, Rubens?

You live, the life you painted blushes with your color [Vivis, vita tuo picta colore rubet]."

2 The last line is a play on Rubens's name, which is the present active participle of the Latin verb rubeo, to redden or blush. ${ }^{2}$ Turning the painter back into a verb, the epitaph implies that Rubens lives through his color and that his color lives through him. It also connects both Rubens and his color to the enlivening spirit of human blood, the circulation of which was first identified in the natural sciences of Rubens's lifetime. ${ }^{3}$ The epitaph, however, was Bellori's invention. ${ }^{4}$

Exemplifying what art historians have long recognized - that such biographies were forms of art criticism and art theory that responded to theoretical concepts visualized in early modern artworks - the imaginary epitaph makes it tempting to see, in Rubens's often effusive uses of the color red, a kind of signature through which he encrypted an authorial presence in his works. ${ }^{5}$

3 This article traces a different idea in Rubens's art, which is that color-paint, with its pigments and mediating liquids - also has a life of its own, a life painting cultivates at a material, elemental level. Indeed, although the epitaph might seem to imply that color achieves life only as a result of Rubens's spirited actions (the furia del penello, or fury of the brush, with which Bellori elsewhere characterizes Rubens's technique), ${ }^{6}$ it ultimately defines the relationship between Rubens and his color as chiasmic or dialectical. It thus emphasizes color itself an intrinsic, animating quality of Rubens's images. This understanding of color as an animating force was formulated by Bellori's 
Dutch contemporary Samuel van Hoogstraten (1627-1678), whose Inleyding tot de Hooge Schoole der Schilderkonst (Introduction to the Academy of Painting, 1678) described color as the "spirit and soul" (geest en ziele) of painting, comparing it to the fire stolen by Prometheus from the gods.

4 A notion of paint as elemental or "vibrant" matter is communicated earlier in Rubens's pictorial engagements with spontaneous generation. ${ }^{8}$ This was the belief, still current in the natural knowledge of Rubens's time, that some life forms or species could be generated directly from decaying matter-birthed, as it were, by nature herself. ${ }^{9}$ Several mythological works by Rubens allude to spontaneous generation, three of which will be the focus here: Head of Medusa (ca. 1613-1618) (fig. 1), which depicts a menagerie of creatures being born from the gorgon's blood; The Discovery of Erichthonius (ca. 1616) (fig. 2), whose subject is the monstrous offspring of Vulcan and Gaia, or Mother Earth; and the late oil sketch Deucalion and Pyrrha (ca. 1636) (fig. 3 ), whose theme is the postdiluvial regeneration of the human race from Gaia's rocks, or "bones." All made in Antwerp, these classicizing allegories of nature model intersections between natural and artistic creation. In this sense, they reflect ideas current in the early seventeenth-century Spanish Netherlands about the close relationship between artisanal knowledge and the knowledge of nature.

5 More than any other premodern scientific belief, spontaneous generation encapsulated the idea of natura naturans, or "nature naturing" - nature as a realm of constant flux. ${ }^{10}$ Seemingly dead matter, broken down and in decay, could mysteriously transmute into a new medium of life. The secret life of nature was a topic of fascination in the seventeenth-century Low Countries, where an atomistic view of matter arose alongside the earliest experiments in microscopy-the technology through which the theory of spontaneous generation would, by midcentury, begin to unravel. In the same period, ideas about nature were strongly shaped by the chemical and manipulative view of matter promoted in the writings and reception of the Swiss physician and alchemist Paracelsus (1493/4-1541). This body of texts often fashioned itself as a "secret" or occult discourse. ${ }^{11}$ As a paradigm for creation, however, spontaneous generation was distinctly ambivalent. Because it did not result in procreation, it bordered on the counternatural and raised anxieties similar to forms of pseudo-creation such as alchemy or the making of automata. ${ }^{12}$ Another such creative enterprise was oil painting, whose techniques were analogized with those of alchemy. ${ }^{13}$ Were paintings truly alive, or were they objects and commodities made of dead matter-natura naturata? If life could arise from dead matter, could the painter's colors, composed of broken-down nature, similarly contain a generative impulse? At what material level and through what techniques could the life of color be cultivated? Rubens's pictured myths of spontaneous generation are an important source for his thinking about such questions. Conceiving of paint as a modality of nature, each centers on a generative substance identified with nature's bodily matter.

6 Studies of art and technology in the early modern Low Countries by Christine Göttler, Karin Leonhard, Sven Dupré, and others have shown the intersections between the "meaning of matter" in early sciences and in artisanal worlds, including those of oil painting. ${ }^{14}$ Recent scholarship has further shown that Rubens's theoretical understanding of painting was closely 
related to his pursuit of natural knowledge, including an interest in Paracelsan concepts of matter. ${ }^{15}$ Indeed, as Teresa Esposito has argued, "the study of nature imbued by current scientific discourse constituted an essential and intrinsic factor within [Rubens's] art theory." 16 Building on this historiography, this essay focuses on Rubens's mythologized scenes of spontaneous generation as a case study for how his artisanal consciousness, informed by ideas about nature's creativity, found expression in his images themselves.

\section{"Discovering" Color in Nature}

7 Before turning to Rubens's depictions of spontaneous generation, I want to consider a late oil sketch in which he depicts the "discovery" of an artisanal dye (fig. 4). Created around 1636 as a preparatory model for the massive pictorial cycle Rubens designed for the Torre de la Parada (a former Spanish royal hunting lodge near Madrid), ${ }^{17}$ it illustrates a legend first recounted in Julius Pollux's Onomasticon, a second-century Greek thesaurus. ${ }^{18}$ One day, Hercules was walking along the shores of Tyre (present-day Lebanon), on his way to see a nymph he loved. A dog walking alongside him found a mollusk in the sand, bit into it, and stained its muzzle with the creature's ink. When the nymph saw the stain on the dog's fur, she was struck by its beautiful color, sparking a local industry for Tyrian purple. Extracted from the secretions of predatory sea snails, purpura was the most precious dye of antiquity, reserved by Roman sumptuary law for imperial dress. ${ }^{19}$ Classical sources often identify purpura as a deep and precious red, the same color Rubens uses to depict the legendary stain. ${ }^{20}$

8 Rubens would likely have understood Tyrian purple as not just any color, but color par excellence. It illustrates perfectly color's ability to transcend its material basis as it moves from nature to culture, from mollusk's blood to a signifier of imperial splendor. Rubens was deeply familiar with such signs of splendor and pomp; he trafficked in them. Yet here he divests from them, reifying color itself and taking us back to nature, to the mollusk and its marvelous secretion. Despite the Latin etymology of Rubens's name, what is most striking about the sketch is not its emphasis on his "signature color," but on that color's basis in living nature. Collapsing the materials of nature and art, it depicts a moment when color occupies a liminal space and subtly identifies the painter with that boundary.

9 The sketch has received relatively little attention in the vast Rubens scholarship, with Svetlana Alpers even admitting to some puzzlement as to why Rubens chose to include the strange scene in the Torre de la Parada cycle. ${ }^{21}$ Only one earlier depiction of the legend is known, in the background of an image of Hercules and Io in the studiolo of Francesco I in the Palazzo Vecchio. ${ }^{22}$ That the erudite Rubens, faced with the task of designing more than one hundred pictures for a hunting lodge, would have chosen an arcane legend featuring a ravenous dog was hardly out of character. Scenes of Hercules in his "downtime" were a Renaissance genre exemplified by the themes of Drunken Hercules and Hercules and Omphale, both of which Rubens had painted earlier in his career, and which thematized Hercules's emasculation in a carnivalesque reversal of his heroic masculinity. ${ }^{23}$ Here, though, rather than milking such antiheroic tropes, Rubens depicts Hercules in a rather quotidian guise, patting a dog's head and 
kneeling on a beach in the moment of "discovering" a color. The sketch emphasizes the sensory environment of discovery: the feeling of fur on skin or warm water lapping on sand; the sight and perhaps sound of a bird flying overhead.

10 The legend encases a history of how and where Tyrian purple was actually produced in antiquity. Yet as Julius Held has argued, Rubens's image may also have referred to a more recent development in the history of color: the discovery in 1630 by the Dutch alchemist, inventor, and engraver Cornelis Drebbel (1572-1633) of how to dye wool a deep red using a solution of cochineal and tin. ${ }^{24}$ Like the discovery of Tyrian purple, this was said to have happened by accident, when Drebbel dropped a flask of aqua regia, a mixture of nitric acid and hydrochloric acid, onto a tin windowsill. ${ }^{25}$ The parallel is strengthened by Rubens's identification of purpura with the color red. As Aneta Georgievska-Shine and Larry Silver have pointed out, the image may therefore also have implied an analogy between ancient Phoenicia and Spain, which had, since the 1520s, been extracting and exporting cochineal red dyes, made from insects, from its colonies in Central America. ${ }^{26}$ Such an interpretation is supported by a canvas painted after Rubens's sketch by Theodoor van Thulden (1606-1669) (fig. 5). ${ }^{27}$ In this larger version, the shells on the beach acquire more variety and specificity, like precious marvels washed ashore. The cooler and darker tones draw attention to the horizon, where ships recede in the sunlit distance or gather in the crowded harbor. The imagery of travel, "discovery," and collecting resonates with the scene's earlier appearance in the studiolo of Francis I, in which the central ceiling fresco, celebrating the Medici natural collections, depicts Prometheus receiving jewels from nature.

11 Two things are worth keeping in mind. First, antiquity could function as an imaginary geography onto which Rubens mapped contemporary concerns, including ones related to the mercantile nexus of the Spanish Low Countries. Second, colors were commodities that, having been extracted from nature-from insects, minerals, stones, clay, berries, tree roots, wood, fossils, bones, and other raw materials-could be understood not only as traces of nature but also as evidence of nature's quasi-artistic impulses. ${ }^{28}$ Modified and transported to new geographies, color became the foundation of further transformations-liquefying, mixing, layering, flowing, scumbling, drying - that evoked nature's own metamorphoses. Such technical and material elisions between nature and painting are the subjects of Rubens's myths of spontaneous generation.

\section{The Bloody Cornucopia: Head of Medusa (ca. 1613-1618)}

12 Re-naturalizing color in nature's hidden vessels, Hercules Discovering Tyrian Purple evokes an earlier, better known work by Rubens, Head of Medusa (fig. 1a), painted in Antwerp around 1613-1618 in collaboration with Frans Snyders (1579-1657). ${ }^{29}$ Two versions of this work exist today: a canvas held in the Kunsthistorisches Museum and originally owned by George Villiers, the Duke of Buckingham (1592-1628); and a panel held in the Moravská Galerie in Brno, whose first owner was most likely the Amsterdam merchant Nicolas Sohier (1588-1642). ${ }^{30}$ Aside from their different surface supports, the two versions are virtually identical. 
13 In each, we see the gorgon's head lying on a precipice of jagged rock. A white shroud or veil wraps around her head, mingling with strands of her hair. Blood gushes from her neck and also seeps from her eyes, nostrils, and mouth. Around the head, snakes, knotted into a complex arrangement, writhe and shimmer in a variety of green, yellow, and coppery brown hues. We seem to be encountering the Medusa at night, in a dark recess brightly and unnaturally lit for our inspection. The tenebristic lighting dramatizes the snakes' movements; light flashes and disappears at intervals, visually animating them. The head's prone position and pale skin make it seem as if the gorgon is both recoiling and hardening-being petrified, in both senses of the word. The right eyelid is peeled back, revealing a bulging eye whose white gleams like motherof-pearl, reverberating with a glint of white impasto. Surrounding this sculpture-in-progress are signs of wild, fast-growing nature: a patch of ivy that springs up from the foreground, ferns and vines crawling up the hillside, and, in the upper left corner, a distant forest stippled in beneath a cloudy nocturnal sky.

14 Baby snakes appear in the wound of the Medusa's neck, a tangle of gore from which a few drops of blood appear to separate themselves, pulsing forward on the precipice. In the Pharsalia (ca. 61 AD), the Roman epic poet Lucan had claimed that when Perseus was flying over Africa with the gorgon's head, drops of her blood spilled to earth and mingled with the soil, generating all of the snakes of Libya. ${ }^{31}$ The Medusa's blood was said by Ovid to have created coral, a story often represented or alluded to in early modern images. ${ }^{32}$ However, Rubens and Snyders are the only artists known to have made the Medusa's generation of snakes the principal subject of an image, conflating the gorgon's death scene with this grotesque birthing scene. Their decision to emphasize the myth's zoological aspect may have been informed by their collaborative process: Snyders, a specialist in the naturalistic depiction of animals, may have been pleased with this novel and dramatic framing of his craft. ${ }^{33}$ In addition to the snakes, the gorgon's blood appears to have spawned an entire menagerie-two spiders, a scorpion, a yellow and black salamander that glances up at us, and a golden snake with two heads-presented on a rustic version of the type of shelves that structured collectors' cabinets. ${ }^{34}$ Emphasized by its positioning directly below the Medusa's right eye, the two-headed snake, known as an amphisbaena, was a topic of discourse in early seventeenth-century natural history. Although fantastical, it had been catalogued by Pliny and by sixteenth-century natural historians such as Conrad Gessner (15161565), who believed it to be a real species-a kind of natural monster. ${ }^{35}$ A specimen had allegedly been discovered in Mexico in 1609, and images of the "Mexican amphisbaena" were disseminated at the Accademia dei Lincei in Rome. ${ }^{36}$ A 1617 painting of a collector's cabinet by Frans Francken the Younger (1581-1642) depicts, among other curiosities, a framed painted study of an amphisbaena that is identical to Snyders's creature (fig. 6) and may reflect a shared and now lost source. ${ }^{37}$

15 Such details starkly differentiate the work from a close predecessor, the Head of Medusa by Caravaggio (1571-1610). ${ }^{38}$ Painted in 1597 on a convex wooden rotella, or round panel crafted to resemble a shield, the version of Caravaggio's work held today in the Uffizi was originally displayed in the hand of a life-size tournament doll in the Medici armory. It was thus understood by early viewers as an apotropaion, a protective image able to turn its owner's 
enemies to stone. ${ }^{39}$ Rubens and Snyders's Head of Medusa has, similarly, been connected to neoStoic philosophical notions, much discussed in Rubens's intellectual circle, about the power of images to both move and immobilize their viewers. ${ }^{40}$ The Amsterdam collector Nicolas Sohier, who owned a version of Rubens and Snyders's Medusa, apparently kept it behind a curtain and unveiled or unleashed it on selected viewers to heighten its effect-an act perhaps alluded to or "doubled" in the veil wrapped over the Medusa's hairline. ${ }^{41}$ Viewers of the painting would have been prompted in an exercise of overcoming their initial terror-which mirrored the Medusa's own pathos at the moment of her death-to reach a state of neo-Stoic apatheia, in which a person is unmoved by the emotions or "passions." ${ }^{42}$

16 This explanation of how the painting constructed its viewers' responses does not, however, fully explain the decision to depict the Medusa's creative acts, refashioning her as an allegory of nature and identifying her blood as an actor, or author. ${ }^{43}$ The excessive blood might have made the image more horrifying, but the Medusa's prone position, a guise that is distinctly more objectified than in Caravaggio's image ${ }^{44}$ also invites a deeper inspection of nature at work.

\section{Marvelous Matter}

17 Significantly, Rubens and Snyders's emphasis on spontaneous generation appears to have been generative for other artists, directly or indirectly inspiring an entire subgenre of baroque painting known as the sottobosco or forest-floor still life. ${ }^{45}$ Most closely associated with the work of the Dutch painter Otto Marseus van Schrieck (1613-1678), this image type offered viewers a glimpse into the mossy, steamy, creatural worlds of the undergrowth-the cycles of creation and decay unfolding just above the earth's surface and in nature's hidden recesses (fig. 7). ${ }^{46}$ As Karin Leonhard has argued, such works fashioned painting as a form of "negative mimesis" akin to spontaneous generation. They therefore offered an alternative to the widespread comparisons between image-making and sexual reproduction. ${ }^{47}$ If the latter drew from the Aristotelian dichotomy of feminine matter and masculine formative spirit, the sottoboschi destabilize this binary by depicting nature atomized into its tiniest particles, revealing the formative impulse within nature's own bodily matter. As Leonhard points out, painters in this genre often employed forms of nature printing, using actual clumps of moss or mushroom spores to print images of the same or embedding real butterfly or moth wings in the painted surface. The maker of such works is conceived not as an Apollonian hero who infuses matter with life, but rather as an artisan who collaborates and cross-fertilizes with nature at an elemental level. ${ }^{48}$

18 The sottobosco genre can, in turn, make us think differently about Rubens and Snyders's painting. We might look again, for instance, at the distant forest whose spongy texture evokes, if not indexes, the use of a natural matrix (fig. 8). The still-life elements may further allude to another type of technical elision between art and nature: life casting. Collectors' cabinets often included metal life casts of reptiles among other types of preserved specimens. The making of such objects entailed molding a freshly killed animal in plaster then replacing it with molten metal, transforming it into a work of art shaped by nature herself. ${ }^{49}$ As Susan Koslow has pointed out, Snyders may well have studied bronze casts of snakes to master the intricacies of 
snakeskin for Head of Medusa. ${ }^{50}$ Not only does the gorgon's head resemble a stone sculpture, but some of the creatures on the precipice-in particular, the amphisbaena and the peculiar coiled reddish-brown snake on the left-appear oddly static, like specimens or, indeed, metal casts. In the final act, then, some of Snyders's creations take their places back where they began, as artificialia displayed on a shelf. At the same time, the amphisbaena's shimmering golden skin and the orgiastic movements of the snakes surrounding the gorgon's head suggest a reanimation of the dead models in full, living color.

19 Recent studies have shed light on Rubens's reception of the Paracelsan alchemical tradition, an aspect of his theory and practice of painting that earlier scholarship had largely overlooked. ${ }^{51}$ Three extant copies of a lost portrait of Paracelsus by Quentin Metsys (1466-1530) are attributed to Rubens or his students. They depict the physician and alchemist holding a book open to the word Quintisense, a pun on Metsys's name that refers to "the alchemical quinta essentia," or fifth element (ether). ${ }^{52}$ Moreover, a transcription of Rubens's lost theoretical notebook, most likely made by his student Anthony van Dyck (1599-1641), contains a recipe for life casting flowers and animals in metal, a technique whose alchemical associations have been explored in depth by Pamela Smith. ${ }^{53}$ Most significantly, Rubens's tract on the human figure, published in Paris in 1773 and one of a handful of essays from the lost theoretical notebook, appears to have contained references to Paracelsan theories about the macrocosmic nature of the human body, including an illustration of three shapes (a square, a triangle, and a circle) that, in Paracelsan alchemy, corresponded to the tria prima, or three primary chemical elements: salt, sulfur, and mercury. ${ }^{54}$

20 In Head of Medusa, nature's finished works are displayed alongside the petrified symbol of nature: the gorgon's head with its deathly, marmoreal coloring. Both are juxtaposed with that which can never be collected or displayed: nature naturing or matter mattering. An amorphous substance both prior and subsequent to the feats of verisimilitude that surround it, the blood is exposed to the viewer only through a violent rupture that reverses creation. In this sense, it evokes the primordial states of matter described in natural philosophical texts. The materia prima or "prime matter," in which the four classical elements (earth, water, air, and fire) were thought to be still mixed together, and the mysterious processes through which this substance evolved into creation and its numberless forms, were the subject of widespread fascination around $1600 .{ }^{55}$ Some artists even made elaborate attempts to represent it. Among the many illustrations for the Utriusque cosmi (1617) of Robert Fludd, an English Paracelsan physician and philosopher whom Rubens may have known, ${ }^{56}$ is an etching that visualizes the earliest phase of the separation of the elements (fig. 9).$^{57}$ Similarly, an engraving, created in 1589 by Jan Muller (1571-1628) after Hendrick Goltzius (1558-1617) as the title page to the pair's Creation of the World series, depicts the sphere of creation pulsing with elemental chaos (fig. 10) ${ }^{58}$ Like such beautifully inscribed clouds or globes, the Medusa's blood gives artistic form to formless matter that seems to pulse with the potential for images; it distills this enlivened matter into tiny droplets, identifying it with color, rather than line. This is achieved by adding small flecks of white and black on either side of each red drop, indicating the separation of lightness from darkness that initiates all creation (fig. 11). To borrow language from the art historian and philosopher George Didi-Huberman, this non-objective, material wonder is "the very symptom 
of painting - the materiality of painting, that is, color, ${ }^{59}$ represented here by the color red and its mysterious fluctuations between matter and form.

21 Technical studies underway at the University of Antwerp may soon determine the actual material basis for the Medusa's blood.$^{60}$ However, whatever the pigment used, the blood may well have alluded, like the bloody stain in The Discovery of Tyrian Purple, to cochineal, the precious red dye obtained from the female specimens of parasitic cactus beetles in Mexico. Transported, like the gorgon's blood, across continents, cochineal was one of the most valuable and heavily traded commodities of the Atlantic world, typically used by European painters only sparingly as an intensifying glaze layered over other reds.61 Situating the gorgon's head on a mountain precipice that recedes into a vast distance, the painting may further represent Mount Atlas-another of the gorgon's creations, which was associated with the Magreb mountain range in Northern Africa. It therefore evokes the myth's wide geographical range, which through the amphisbaena now includes not only northern Africa but also Mexico. Though Perseus is absent, he is implied both as the ideal princely viewer and as the traveling hero who flew around the world carrying his marvelous prize: the head of Medusa and her blood.

22 Another red colorant the blood might have invoked was vermilion, a pigment with a history of local production in Antwerp. ${ }^{62}$ Derived in antiquity from cinnabar, a byproduct of mercury mining, vermilion had been produced synthetically in Europe since the Middle Ages by mixing mercury and sulfur to form a black mercury sulfide. When heated in a retort, this compound vaporizes and recondenses in red crystals that can then be extracted and ground up to produce the pigment. ${ }^{63}$ Yet as Cennino Cennini had already remarked in his Libro dell'Arte (ca. 1400), vermilion was unstable and had a tendency to darken over time, reverting to its original blackness. ${ }^{64}$ Because of this instability and oscillations between red and black, which mirrored and likely informed descriptions of alchemical transmutation, vermilion was strongly associated with alchemy, a "meaning of matter" that Head of Medusa's generative imagery exploits. ${ }^{65}$

23 Joachim von Sandrart (1606-1688) claimed that when an alchemist once visited Rubens, inviting him to fund his experiments, Rubens replied that he had already “found the true philosopher's stone in [his] brushes and colors." ${ }^{16}$ Emphasizing painting's life-giving potential, the anecdote is also a wry statement about Rubens's commercial success and how "brushes and colors" reside at the crossroads of unstable and fluctuating material values. A center of the maritime trade in luxury commodities, Antwerp had developed a vibrant artisanal culture by the first half of the sixteenth century. Its practitioners responded to the city's "feverish capitalistic boom" 67 intensively navigating their own role in transforming nature through artifice and in manipulating materials. ${ }^{68}$ By the early seventeenth century, when Antwerp's mercantile economy was in steep decline due to the war between Spain and the rebellious Northern Provinces, such manipulations, particularly those of oil painting, took on an outsized meaning in Antwerp's visual culture. Painters in Rubens's circle frequently analogized their artistry both with alchemy and with the actual production of currency (for instance, in depictions of Vulcan's forge), emphasizing the fundamental instability of the material world and the value of artisanal knowledge. ${ }^{69}$ Presenting the gorgon's blood in flux, Head of Medusa epitomizes a cultural 
understanding of color as "mercurial" in the deepest sense-both mutable and transformative, subject to manipulations and the agent of such manipulations.

\section{Generative Wounds}

24 The gorgon's blood is also an authorial interstice, a space between hands. It is not immediately clear who would have painted it, Rubens or Snyders. However, technical studies of early seventeenth-century Flemish collaborative paintings show that the figure painter typically executed his work first, leaving a reserve space for his collaborator to fill in later. ${ }^{70}$ Here, then, Rubens's overflow, the substance that erupts from his own "still life" of the petrifying head, becomes the raw material for Snyders's still life as well. The painters are implied as co-sanguine in their work.

25 The emphasis on a regenerative wound resonates with another Rubens-Snyders collaboration of this period, Prometheus Bound (ca. 1616) (fig. 12). ${ }^{71}$ As Elizabeth Honig has shown, such Flemish collaborative paintings were aimed at an audience of savvy amateur collectors, or liefhebbers, who could take pleasure in recognizing the various hands at work. ${ }^{72}$ Both Head of Medusa and Prometheus Bound reflect this competitive and self-conscious artisanal culture in which painters marketed and mythologized their skills and, as argued here, their materials. ${ }^{73}$ Depicting their protagonists in vertiginous rocky settings, and divided with a striking evenness between figure and still life, both paintings demonstrate Rubens's ability to depict extreme ontological and emotional states, as well as Snyders's mastery of the complex textures of feathers and scales.

26 Both also feature mythological protagonists deeply associated with the visual arts. According to the version of his myth attributed to Aeschylus, Prometheus was the archetypal human creator in competition with the gods whose theft of fire from Mount Olympus was the foundation of human technology, culture, and the arts. ${ }^{74}$ The Renaissance authors Pomponius Gauricus (De Scultura, 1504) and Natalis Comes (Mythologiae, 1567) identified Prometheus specifically as a sculptor. ${ }^{75}$ The Medusa, in turn, was both a victim of metamorphosis (her hair transformed by the angry Minerva into snakes) and an agent of it, able to petrify living bodies with her gaze and to create new species with her blood. As Caroline van Eck has argued, her myth therefore "offers among the most versatile and ambivalent paradigms of the emergence of figuration or ikonopoesis-literally the making of images of living things-both in sculpture and in painting." 76

27 Rubens depicts Prometheus chained upside-down to the mountainside while an eagle pecks out his liver, a punishment that-according to some versions of the myth-was repeated endlessly, since the liver grew back each day. ${ }^{77}$ An ekphrasis on the painting by the Dutch poet Dominicus Baudius (1561-1613), sent to Rubens in a letter of 1612, describes how Snyders's creature seems to "beat the air with its wings" and "eject savage flames" from its eyes. ${ }^{78}$ It is as if Snyders picked up the torch depicted in the lower left corner and enlivened his work with the fire Prometheus stole, claiming the torch specifically for painting, rather than sculpture. Baudius's poem also links the fire to Prometheus's exposed blood: "Blood oozes from the chest of Prometheus and 
colors every spot where he treads his claws. The piercing eyes eject savage flames." ${ }^{\prime 79}$ The eyes of Snyders's eagle indeed blaze fiery red (fig. 13). Baudius's text, and the visual cues to which it responds, anticipate Hoogstraten's later comparison of the Olympian fire to color, an instance of a Flemish collaborative painting anticipating rather than reflecting written art-theoretical discourse. $^{80}$

28 Once more, Rubens concentrates this pictorial enlivenment, the fiery "geest en ziele" of painting,in a wound (fig. 14). Like the gorgon's blood in Head of Medusa, Prometheus's liver is situated at the image's compositional and narrative center. These works thus dramatize painterly collaboration in the form of a violent clash, inviting their viewers to make a chain of competitive comparisons: between figure and still life, sculpture and painting, and creative powers human, natural, and divine. ${ }^{81}$ Both paintings construct intricate representations around exposed sites of regenerative bodily matter that appear physically internal to the images themselves. In this way, they implicitly naturalize the life of painting within its materials, characterizing matter as an active agent in artistic creation and as an analogue of, rather than an opposite to, the artist.

\section{Living Liquids: The Discovery of Erichthonius (ca. 1616)}

29 The Discovery of Erichthonius (ca. 1616) is among Rubens's strangest mythological scenes (fig. 2a). ${ }^{82}$ Like Head of Medusa, it depicts Mother Nature in a polarized form, as both a female sculptural body and the generative liquid that erupts from it. According to Ovid, when Vulcan tried and failed to rape Minerva, his seed spilled onto the earth, accidentally mating with the mythological Earth Mother, Gaia. Their offspring was Erichthonius, a human infant with serpentine lower limbs. After his birth, Minerva shut him in a box, which she gave to the three daughters of the Attic king Cecrops, warning them never to look inside. Rubens depicts the moment when one of the girls, Aglaurus, disobeys, revealing the monster to her sisters. ${ }^{83}$ The scene is set in an ornate Flemish garden filled with antiquarian objects, the largest and most prominent of which is a mossy stone fountain statue of Diana Ephesus, an ancient herm that in the Renaissance had become an emblem of nature's fertility. ${ }^{84}$

30 This odd tale of spontaneous and monstrous generation was rarely depicted in the early modern period outside of illustrated Ovids. ${ }^{85}$ However, several versions of Rubens's depiction of the scene survive, including a preliminary oil sketch at the Courtauld (fig. 15), at least two highly finished modelli, a finished canvas painting, and a print made after Rubens's design by Pieter van Sompel (ca. 1600-1643). ${ }^{86}$ Svetlana Alpers has interpreted Rubens's image as a classicizing "allegory of the fertility and diversity of nature." ${ }^{87}$ In the Courtauld sketch, the Ephesian fountain takes up much of the extant surface. Sixteenth-century emblems identify Diana Ephesus simply as Natura, an association that also extended to Gaia, or Mother Earth. ${ }^{88}$ Erichthonius's mother is therefore present at the scene in sculptural form. In all extant iterations of Rubens's image, the statue appears to be as vivacious as the "living" figures, even if its grisaille coloring also cordons it off as a symbolic, unnatural body. Its eyes roll upward, conveying both a grotesque ecstasy and a certain ontological ambivalence befitting a statue. The gray coloring of Erichthonius's serpentine legs seems to confirm a kinship with the statue; as he does in Head of 
Medusa, Rubens asserts a bizarre affinity between a petrified female body and her serpentine creation. In the large canvas painting, the scene expands to include a boy, an old woman grinning satirically at the viewer, and a landscape with gridded planting beds. The grotto containing the fountain is encrusted with a variety of glossy shells and a red coral branch, and further decorative objects appear in the garden, including a herm of Pan and a vase ornamented with a winged head of Medusa (gorgoneion). In this garden, Nature is represented either by her specimens or in the various symbolic forms given to her by artists. She is natura naturata, "natured nature." One exception, however, merits consideration.

31 The fountain's wide basin cuts off Diana at the waist, beneath which a silvery cascade of water flows. Water also streams from Diana's breasts and from the open mouths of the carved dolphins at her sides. Rubens's depiction of the Ephesian herm as a fountain statue in a grotto may have been inspired by examples he had seen in Italy. ${ }^{89}$ It also enables him to identify a sculptural fragment as the maternal source of the "real," living, flowing world. Seen also in Head of Medusa, the Rubensian topos of the liquefying statue visualizes theoretical ideas found in another section of the lost theoretical notebook, De imitatione statuarum. ${ }^{90}$ In this text, Rubens encourages painters to study and make copies after ancient statues, which captured the human body in the perfect form it had achieved in antiquity. ${ }^{91}$ The goal of this copying was not imitation, however, but absorption and reanimation. According to Rubens, in order to wrest the living figures from the hard material in which they had been calcified, painters should "be imbibed" with ancient statues (imo imbibitionem), ${ }^{92}$ a process implying liquefaction or even transmutation. Rubens's scenes of spontaneous generation reflect this theoretical association of painting with mutable, liquid matter that sparks life. In The Discovery of Erichthonius, Gaia, personified in ancient stone, is reanimated by water that sets her generative processes once more into motion. Like the gorgon's blood, the water that flows from the statue construes painting as tapping into a vital wellspring, and the painter as someone who transacts in nature's hidden creative energies. ${ }^{93}$ A century earlier, Lorenzo Lotto (ca. 1480-1566/7) had portrayed the antiquarian merchant Andrea Odoni holding a statuette of Diana Ephesus, an emblem of the mysteries of nature and antiquity alike (Windsor Castle, 1527). Rubens elides the two: brimming with water, his Ephesian herm once more becomes a living source. The moss on the basin and the vines that crawl around the shells confirm the life force hidden in old works of stone.

\section{De generatione humanum: Deucalion and Pyrrha (ca. 1636)}

32 The latent force of earth mixed with liquid and heat is the subject of Rubens's late oil sketch Deucalion and Pyrrha (ca. 1636; fig. 3a). Created, like the oil sketch for The Discovery of Tyrian Purple, for the Torre de la Parada cycle, it depicts the regeneration of the human race following the cataclysmic flood unleashed by Zeus. ${ }^{94}$ Deucalion was the son of Prometheus, who survived the deluge together with his wife Pyrrha by floating in a chest built by his artisan father. However, the couple was elderly, diminishing the chances for humanity's survival. As the rains fell, the oracle at Themis told Deucalion: "Cover your head and throw the bones of your mother behind your shoulder." Deucalion correctly interpreted this to mean rocks-the "bones" of Gaia-which he and Pyrrha cast behind themselves and which spontaneously metamorphosed 
into human beings. ${ }^{95}$ Thus, although not presented in the form of a statue, Mother Earth is once more allegorized in stone, a material that precedes the creation of life. The scene was most likely paired in the Torre de la Parada with another myth of spontaneous generation, Cadmus Sowing the Dragon's Teeth.${ }^{96}$ According to Ovid, Cadmus killed the dragon that guarded the spring of Ares. Lacking an army, Cadmus planted the dragon's teeth in the earth, and the teeth immediately sprouted into armed warriors who began battling one another. ${ }^{97}$

33 Both images correspond to a period fascination with rocks, stones, and mineral formations as sites where the opposition between matter and form breaks down, exposing the "metamorphic potential of matter" itself. ${ }^{98}$ Fossils and legendary images believed to have been produced naturally within stones represented the concept of nature as artist, a driving aesthetic principle of collectors' cabinets. ${ }^{99}$ Leon Battista Alberti (1404-1472) claimed that the first sculptures originated from early humans discerning the lineaments of bodies in a tree stump, a clod of earth, or other conglomerations of raw matter. ${ }^{100}$ Elsewhere, Alberti stated that "nature herself delights in painting," citing such pictorial stones as an example. ${ }^{101}$ A related notion was that painters could take inspiration from the forms they perceived in clouds, stains, or other organic masses, or could even incorporate material accidents into their works by, for instance, throwing a sponge at the canvas. ${ }^{102}$ Rubens's awareness of the art-theoretical topos of the "image made by chance" is shown by his late oil sketch Neptune Calming the Tempest (1635), which depicts the fugitive north wind, Boreas, as a cloud-figure (fig. 16). ${ }^{103}$ Created just one year later, the Deucalion and Pyrrha sketch seemingly takes such notions to the extreme by depicting a myth in which fragmented nature actually generates living bodies. There is a capriciousness to the act of throwing the rocks that, like the image of the Medusa's spilling blood, situates creation within nature's material flux. Here, however, humans are shown facilitating the creative process; Mother Nature, apparently, needs collaborators.

34 Deucalion and Pyrrha conduct their work in the muddy foreground before a temple. In the background we glimpse a sea, perhaps the flood receding. Above the uneven, wet-looking ground is a sky tinged with yellow, blue, and pink, the colorful brushwork punctuated by two tiny birds in flight. Deucalion hurls two rocks behind him while Pyrrha throws one rock and bends down to pick up another. Their hunched poses and long, bent arms convey a sense of syncopated, wheel-like motion. On the right stand their first creations, a naked couple who resemble Rubens's earlier depictions of Adam and Eve. ${ }^{104}$ In contrast to the pugnacious warriors sowed by Cadmus, these figures turn to each other and embrace, as if about to begin procreating instantly. ${ }^{105}$ Other figures emerge from the ground: a male nude who looks up at the flying rocks as if awaiting his own mate, and two additional half-baked creations struggling out of the muck (fig. 17).

\section{Origins and Prototypes}

35 Illustrated Ovids from the late sixteenth and early seventeenth century, from which Rubens frequently drew pictorial inspiration, had depicted Deucalion and Pyrrha's progeny as a group of infants or children crawling around the ground (fig. 18). ${ }^{106}$ Rubens's decision to show these 
creations instead as adults, differentiated according to various states of finish rather than age, emphasizes the speed and spontaneity of this primordial anthropogenesis. It also more clearly distinguishes this "spontaneous" generation from the history of procreation that follows. Rubens's reinterpretation of the scene also invites the viewer to compare the different types of human bodies the image shows. Muscular and gigantic, Deucalion and Pyrrha seem to belong to a different age of the earth than their soft, lissome progeny. This epochal juncture, the transition between two ages in the history of humans, may have implied a stylistic or art-historical break as well. Deucalion and Pyrrha are reminiscent of the sculptural, monumental figures of Michelangelo (1475-1564). ${ }^{107}$ Their robes, in particular, recall those of Michelangelo's prophets and sibyls in the ceiling of the Sistine Chapel. In contrast, the fleshy, pinkish nudes that sprout from the earth are distinctly Titianesque. This is not surprising, since Rubens's conception of Adam and Eve was filtered through Titian (1490-1576), whose painting The Fall of Man he had copied in Madrid. ${ }^{108}$ The reference would have been recognizable to the work's intended Spanish audience.

36 For Rubens and his viewers, the bald, naked humans still half-embedded in the earth may have evoked additional prototypes. They are reminiscent of late sixteenth-century sources that characterize the Indigenous inhabitants of the Americas as lacking form, spirit, and humanity until receiving it from their colonizers. ${ }^{109}$ In addition to the engravings of Theodor de Bry (1528-1598), which frequently emphasize the amorphous quality of the "new world" and its inhabitants, ${ }^{110}$ there are clear similarities between the anthropogenetic imagery of Rubens's Deucalion and Pyrrha and the allegory of America from the print series titled Nova Reperta (New Inventions and Discoveries), executed after Jan van der Straet (1523-1605) and published in the 1590s by Philip Galle (1537-1612). ${ }^{111}$ In this print (fig. 19), the continent is allegorized as an Indigenous woman eagerly rising from her hammock as she is "awakened" by Amerigo Vespucci (1451-1512). The image's caption reads, "Amerigo rediscovers America; he called her but once and thenceforth, she was always awake." 112 In the rocky background, a fictionalized Indigenous group is shown practicing cannibalism. Huddled close to the earth, these earthly, inchoate bodies appear to be called to life, in the foreground, by the allegorical figure of America that rises through Amerigo's Pygmalionesque act.

37 José de Acosta's Natural and Moral History of the Indies (1590), a text Rubens owned and had used three years earlier as a source for the Pompa introitus Ferdinandi (a triumphal procession designed by Rubens and held in Antwerp in 1634), ${ }^{113}$ specifically mentions "Deucalion's flood" in a chapter on "what the Indians tell about their origins":

Some experts say that in those countries are many notable signs of some great flood, and I am of their opinion that these marks and signs of a deluge was not that of Noah, but some other particular flood such as that of which Plato speaks, or Deucalion's flood, of which the poets sing. ${ }^{114}$

38 De Acosta's text then maps these ancient floods onto an origin myth of the post-diluvial regeneration of the Incas out of Late Titicaca by the god Viracocha. ${ }^{115}$ The subjects of Rubens's image-humanity and its natural history-were categories that were being intensively 
questioned and revised in early seventeenth-century Europe in response to such sources. ${ }^{116}$ Given that Rubens's sketch was probably a preparatory model for a larger canvas sent to Madrid, an uncomfortable aspect of the work is therefore the rhetorical contrast or even racial hierarchy implied in its presentation of a blond, Titianesque Adam and Eve as the apotheosis of humanity. ${ }^{1}$

\section{Technologies of Earth}

39 Like the baby snakes emerging from the Medusa's blood, the bodies that rise from the earth in Deucalion and Pyrrha are monsters-not in the sense of being chimeras, but in the sense of being incomplete creatures caught between matter and form. Hairless, faceless, and without apparent gender, they are indicated with a few smears of blue-gray, yellow, and brown over the ochre ground. One lies prone with one elbow bent, apparently trying to rise out of the muck. Triangular shadows appear in the crevices where this body separates from the ground, echoing the modeling of the rock that Pyrrha holds up against the sky. That rock's three visible facets, in three shades of gray, suggest-like the drops of the gorgon's blood-a kind of kernel or code for all three-dimensional bodies (fig. 20). Despite the association that Rubens's early biographers made between his art and colore (coloring), as opposed to disegno (design), Deucalion and Pyrrha reveals an equal fascination with the potency of light and dark and how the "seeds" of images are contained in the rudiments of volumetric form. ${ }^{118}$

40 Rubens's sketch also relates the collaboration between painting and Gaia to the fluctuating and mixed materiality of paint. Indeed, its earliest viewers would have included other artists as well as learned connoisseurs, for whom painting's techniques were increasingly of interest. Depicting nature as a technological realm, the image emphasizes the deep knowledge of materials and their transformation that was attributed to artisans in early seventeenth-century Antwerp and that was understood as a form of knowledge about nature. ${ }^{119}$

41 The lush brushwork and unblended, vibrating colors of Deucalion and Pyrrha communicate a material world in flux. Such painterliness is typical of Rubens's late oil sketches, in which the poetics of spontaneity-the spontaneous generation of images-derive from rapid execution and what David Freedberg has described as an astonishing "fluency," a near elision of thought and action. ${ }^{120}$ The fluency of Rubens's late oil sketches is also a material-technical quality aided by the use of an actual fluid: turpentine. Particularly from about 1615, Rubens's paintings show evidence of a substantial use of oil of turpentine, a solvent made from distilled pine resin. ${ }^{121}$ The significance of this liquid to Rubens's technique is documented in a note in the "Mayerne manuscript." This compilation of more than three hundred handwritten notes and recipes on artisanal technologies was assembled and transcribed between about 1620 and 1646 by Théodore Turquet de Mayerne, a Geneva-born physician whom Rubens knew. ${ }^{122}$ Held today in the British Library, the manuscript includes a technical note whose source it identifies as "M. Rubens": 
To make your colours spread easily, \& by consequence to mix well, $\&$ even don't die [ne meurant pas] ... when painting, dip your brush lightly from time to time into the white oil of Turpentine from Venice extracted au bain M.[arie] then with the said brush mix your colours on the palette. ${ }^{123}$

42 Rubens thus appears to have practiced and advised distilling turpentine in a bain-marie, a heating vessel also used in alchemy (fig. 21). Dipping the brush in this warm liquid, the note suggests, allows the painter to control the viscosity of his colors and to preserve their liveliness. ${ }^{124}$ While the phrase ne meurant pas might be understood in a more practical sense as "not discolor," the evocative reference to the possibility of colors dying also conceives of paint as an organic substance open to life-giving manipulations.

43 Scholars have noted how Rubens's richly varied paint surfaces invoke the human body's layers, an analogy also found in his theoretical writings. ${ }^{125}$ While Rubens's impasto brushwork conveys the fleshiness and materiality of color, this is typically combined with translucent areas where paint is applied in thin layers or glazes, communicating the diaphanousness of human skin. Such thinly painted areas often reveal glimpses of the preparatory layer known in Italian as the imprimatura and in Dutch the doodverf (dead coloring). ${ }^{126}$ This layer, applied rapidly and with a coarse brush, is often incorporated by Rubens as a kind of special effect, imparting a dynamic atmosphere to his landscapes and the illusion of living, breathing flesh to his bodies. In Deucalion and Pyrrha, the doodverf supplies a visible basis for the fictive ground that is also Mother Earth herself, imbricating the technologies of nature and painting. Deucalion and Pyrrha's first creations display this dual parentage-particularly the Ovidian "Eve," who incorporates the earthy ground coloring in her torso and her hair. ${ }^{127}$ That such preparatory layers heavily feature earth pigments such as chalk and ochre would have given the analogy between color and Gaia's bodily matter real material weight.

44 In the preface to his Lives of the Artists, Giorgio Vasari (1511-1567) explicitly linked the Biblical creation of mankind to the earthly origins of pigments:

Now, the first model [modello] from which the first image of a man emerged was a lump of clay [terra]. And not without reason: because the divine architect of time and nature wanted to show perfectly in the imperfection of the material how to remove and to add, in the same way that sculptors do.... He gave [his model] vivid flesh coloring; and later on the same colors, derived from quarries [miniere] in the earth, were to be used to fashion [contraffare] all the things that occur in paintings. ${ }^{128}$

45 Deucalion and Pyrrha follows the progression in Vasari's text from sculpture to painting. It emulates sculptural techniques-modeling, chiseling-in order to transcend them through color. This is especially apparent in the sky, the metamorphic space through which Gaia's "bones" first pass on their way to becoming living bodies (fig. 22). Bridging the two sides of the composition, the sky's brushwork displays an optical mixture of red, blue, and yellow mixed 
with white. The sky is reminiscent of discussions in the optical treatise by François d'Aguilon, which Rubens had illustrated and which was one of the earliest works to formulate the theory of red, blue, and yellow as the "primary colors." ${ }^{129}$ Rubens's sketch implies that these exemplary colors are necessary ingredients in the creation of truly living bodies, as is a quasi-alchemical mixture of the elements. ${ }^{130}$ The landscape's Paracelsan overtones are further revealed through a comparison with an etched illustration in Atalanta fugiens (1618), an alchemical emblem book by the German physician and alchemist Michael Maier. The caption for a landscape etching created by the Swiss-German printmaker Matthäus Merian (1593-1650) and labeled as Emblem 36 (fig. 23) describes the philosopher's stone being "cast upon the earth" (lapis projectus est in terras). ${ }^{131}$ In fact, Merian depicts the philosopher's stone as three stones in flight, just as we see in Rubens's sketch. As Michael Gaudio notes in a recent article on the Atalanta fugiens illustrations, "Merian represents the stones as cubes, and to accommodate their elemental course through earth, air, and water, he sets them within a flourishing river valley." 132

In Rubens's sketch, the "dead coloring" comes to life in the postdiluvial landscape through the mixing of earth, water, air, and the fiery warmth in the sky, which crests in the pink and yellow streaks of impasto that run just under Pyrrha's rock. Comparing elemental mixing to the mingling of the primary colors, the image elides the materials and technologies of nature and painting. Such details suggest Deucalion and Pyrrha as a case study for how a late Rubens oil sketch such as this could have functioned not just as a model for a finished, exported canvas painting but also as an art-theoretical and discursive object in its own right within the workshop. ${ }^{133}$ Associated with sculptural creation, its industrious, perpetually laboring Titans appear blind to the ultimate creative act, which takes place both within the mythological scene of spontaneous generation and at the level of its making.

\section{Conclusion: Mythologizing Matter}

47 Rubens's images of spontaneous generation dramatize moments when a mythological substance-color, identified with nature's bodily matter-becomes a medium of creation. The blood that oozes from the gorgon's neck in Head of Medusa, the water that exits the Ephesian fountain in The Discovery of Erichthonius, and the rocks that hover over the "common ground" between Gaia and painting in Deucalion and Pyrrha: all of these articulate the materials of nature and painting seeping into each other. In two of these works, Head of Medusa and Deucalion and Pyrrha, nature actually becomes an artist, her creativity unfolding in narrative time. Intriguingly, in both, nature's generative acts are performed by substances etymologically linked to Rubens's name: the blood in Head of Medusa relates to Rubens ("reddening"), and the rocks in Deucalion and Pyrrha to Petrus, or Peter. ${ }^{134}$ Such references, if Rubens did intend them to be recognized by viewers, would merely have amplified what the images already emphasize: the inextricability of matter and making. Analogizing painting (if not the painter himself) with nature's oscillations between matter and form, softness and hardness, wetness and dryness, stillness and motion, these works imply artistic agency as both external to and present within painting's materials. 
48 To conclude, let us briefly return to The Discovery of Tyrian Purple and its possible allusion to Cornelis Drebbel's discovery of how to chemically manipulate cochineal red dyes. In a letter of 1629 to the French antiquarian Nicolas-Claude Fabri de Peiresc, Rubens poked fun at Drebbel, whose work and physical appearance, he slyly noted, both fell apart under close inspection and were thus best viewed from afar-an insulting dig at Drebbel's widely known experiments with microscopic lenses. ${ }^{135}$ In The Art of Describing (1983), Svetlana Alpers cites this letter as evidence for a broad distinction between Drebbel's "technical and manipulative view of the world" and Rubens's more "textual and historical concerns." ${ }^{36}$ However, the works examined in this essay have shown that Rubens's "technical and manipulative" understanding of his craft, informed by ideas about nature's creativity and about matter itself, could structure his interpretation of ancient myths as much as his antiquarian erudition. Weaving together various originary realms - nature, antiquity, and the global geography through which Rubens's materials and subject matter were constituted-these scenes of spontaneous generation situate painting at the crossroads.

\section{Acknowledgements}

This essay would have been inconceivable without the insights offered at various points in time by Frank Fehrenbach, Shawon Kinew, Joseph Koerner, Claudia Swan, Joanna Woodall, and others who are thanked in the footnotes. I am also thankful to the two anonymous reviewers and Perry Chapman for their incisive comments on an earlier draft.

\section{Biography}

Marisa Mandabach received her PhD in the History of Art and Architecture from Harvard University and is currently an adjunct lecturer in the Kunstgeschichtliches Seminar at the University of Hamburg.

\section{marisamandabach@gmail.com}

\section{Illustrations}

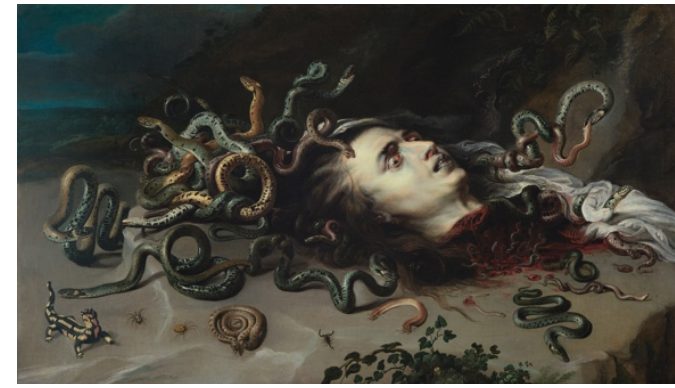

Fig. 1 Peter Paul Rubens and Frans Snyders, Head of Medusa, ca. 1613-1618, oil on canvas, $68.5 \times 118 \mathrm{~cm}$, Kunsthistorisches Museum, Vienna, inv. No. GG 3834

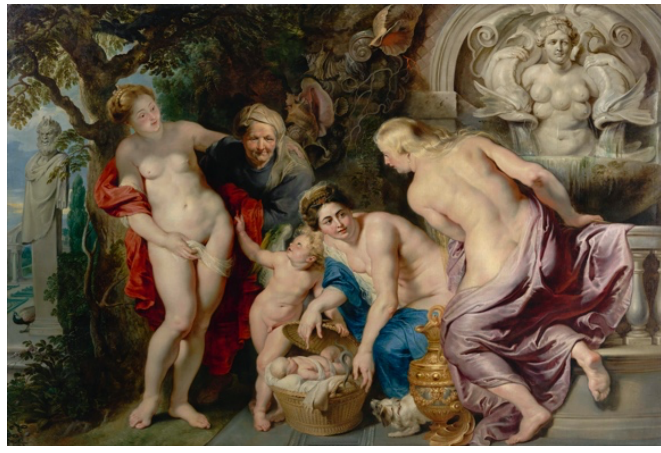

Fig. 2 Peter Paul Rubens, The Discovery of Erichthonius, ca. 1616, oil on canvas, 218 x $317 \mathrm{~cm}$. Liechtenstein Museum, Vienna, inv. no. GE111 


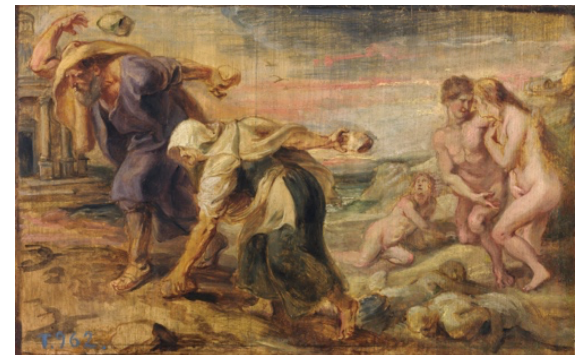

Fig. 3 Peter Paul Rubens, Deucalion and Pyrrha, 1636, oil on panel, $26 \mathrm{x}$ $40.7 \mathrm{~cm}$. Museo del Prado, Madrid, inv. no. 2041

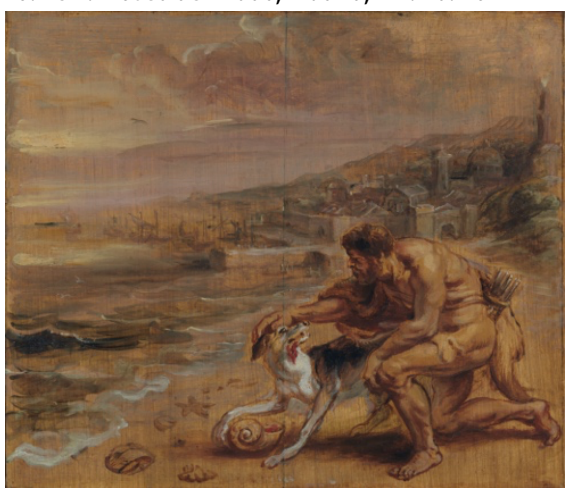

Fig. 4 Peter Paul Rubens, The Discovery of Tyrian Purple, ca. 1636, oil on panel, $28 \times 32.6 \mathrm{~cm}$. Musée Bonnat-Helleu, Bayonne, photography by A. Vaquero

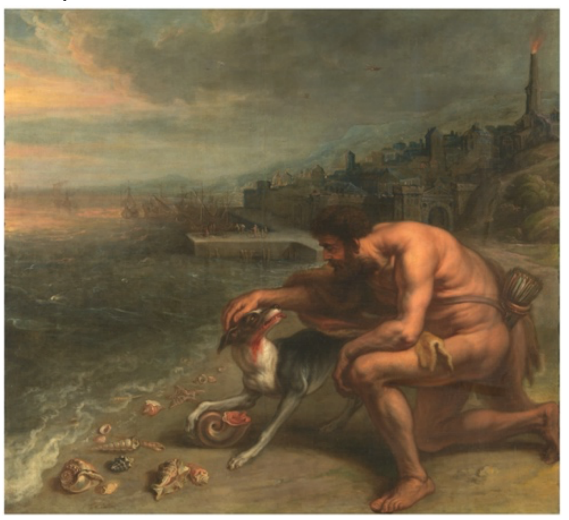

Fig. 5 Theodor van Thulden after Peter Paul Rubens, The Discovery of Tyrian Purple, ca. 1636-1638, oil on canvas, $190 \times 211$ cm. Museo del Prado, Madrid, acc. no. P001845

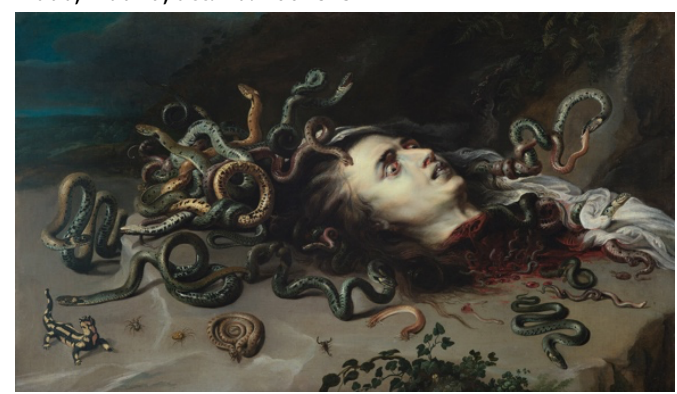

Fig. 1a Peter Paul Rubens and Frans Snyders, Head of Medusa, ca. 1613-1618, oil on canvas, $68.5 \times 118 \mathrm{~cm}$, Kunsthistorisches Museum, Vienna, inv. No. GG 3834

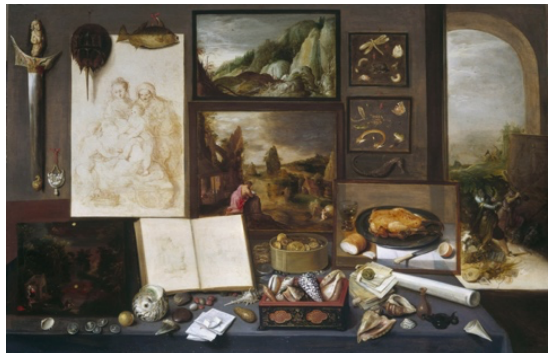

Fig. 6 Frans Francken the Younger, Cabinet of a Collector, signed and dated 1617, oil on panel, $76.5 \times 119.1 \mathrm{~cm}$. Royal Collection Trust, London, RCIN 405781, @ Her Majesty Queen Elizabeth II, 2021

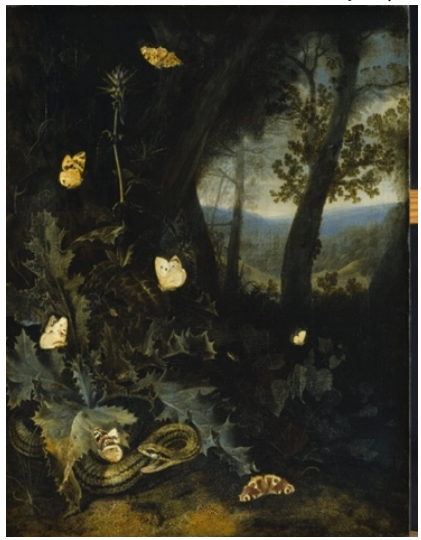

Fig. 7 Otto Marseus van Schrieck, Forest Floor with Thistle and a Snake, ca. 1655, oil on canvas, $68.4 \times 53 \mathrm{~cm}$. Staatliches Museum Schwerin, photography by Elke Walford, courtesy BPK and Staatliche Schlösser, Gärten und Kunstsammlungen Mecklenburg-Vorpommern

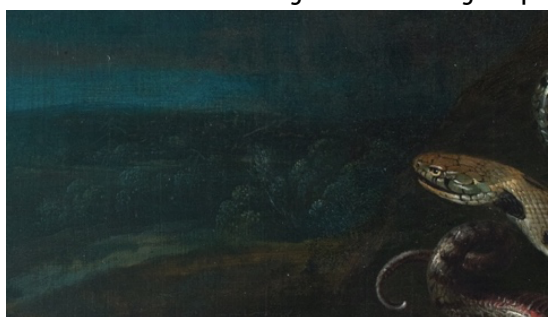

Fig. 8 Peter Paul Rubens and Frans Snyders, Head of Medusa (fig. 1), detail of the forest

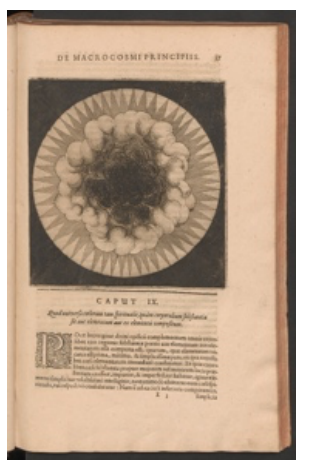

Fig. 9 Primordial Chaos, ca. 1617, etching, in Robert Fludd, Utriusque cosmi maioris scilicet et minoris metaphysica, physica atque technica historia in duo volumina secundum cosmi differentiam divisa (Oppenheim, 1617), 1:37. Courtesy of Stiftung der Werke von C.G. Jung, Zürich (artwork in the public domain) 


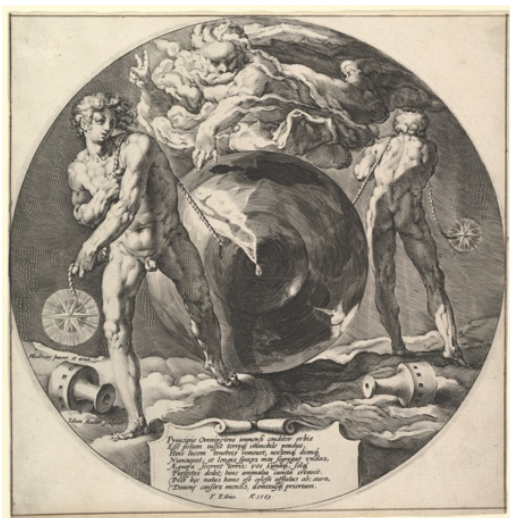

Fig. 10 Jan Muller after Hendrick Goltzius, Creation of the World, ca. 1592, engraving, second state of two, plate: $26.4 \times 26.4 \mathrm{~cm}$. Metropolitan Museum of Art, New York, metmuseum.org (artwork in the public domain)

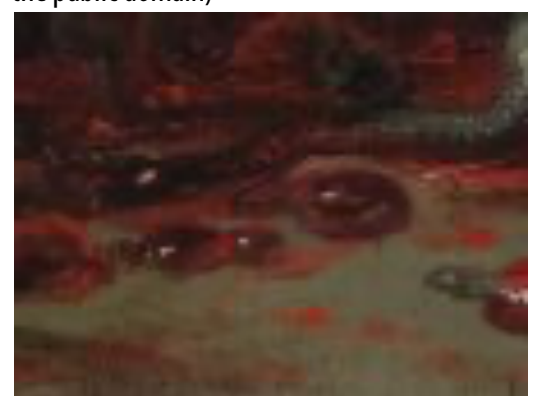

Fig. 11 Peter Paul Rubens and Frans Snyders, Head of Medusa (fig. 1), detail the Medusa's blood

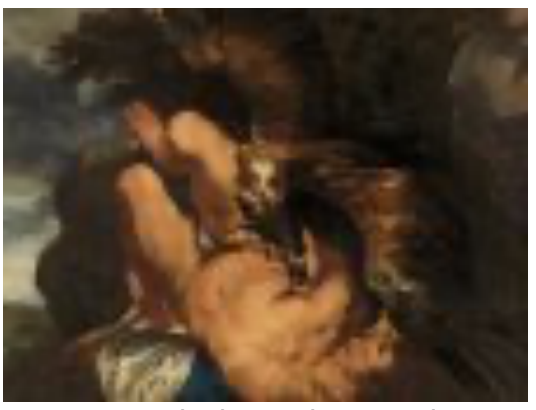

Fig. 12 Peter Paul Rubens and Frans Snyders, Prometheus Bound, ca. 1611-1612 to 1618, oil on canvas, $242.6 \times 209.6 \mathrm{~cm}$. Philadelphia Museum of Art, Philadelphia, Purchased with the W. P. Wilstach Fund, 1950, W1950-3-1, image Courtesy of the Museo del Prado, 2015

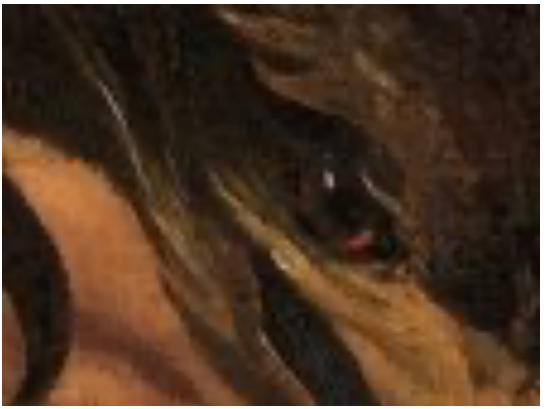

Fig. 13 Peter Paul Rubens and Frans Snyders, Prometheus Bound (fig. 12), detail of the eagle's eye

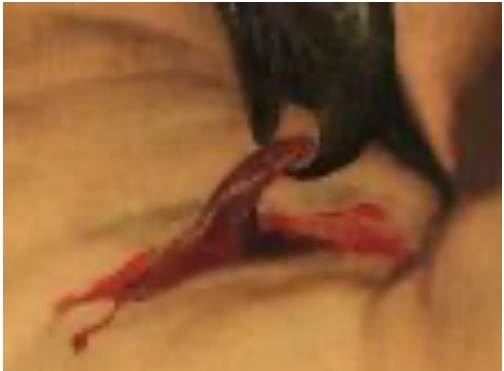

Fig. 14 Peter Paul Rubens and Frans Snyders, Prometheus Bound (fig. 12), detail of Prometheus's liver

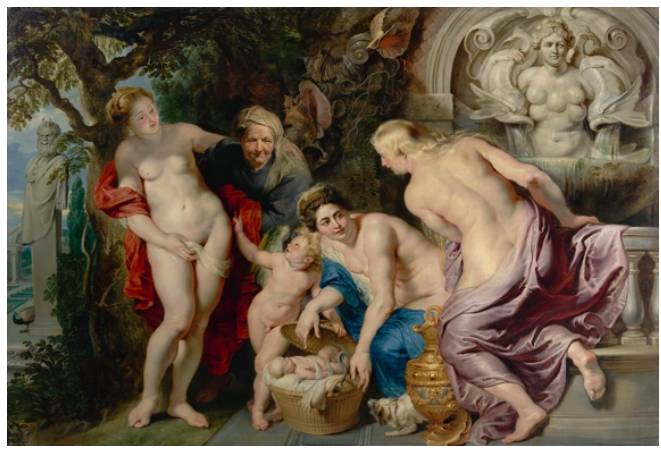

Fig. 2a Peter Paul Rubens, The Discovery of Erichthonius, ca. 1616, oil on canvas, $218 \times 317 \mathrm{~cm}$. Liechtenstein Museum, Vienna, inv. no. GE111

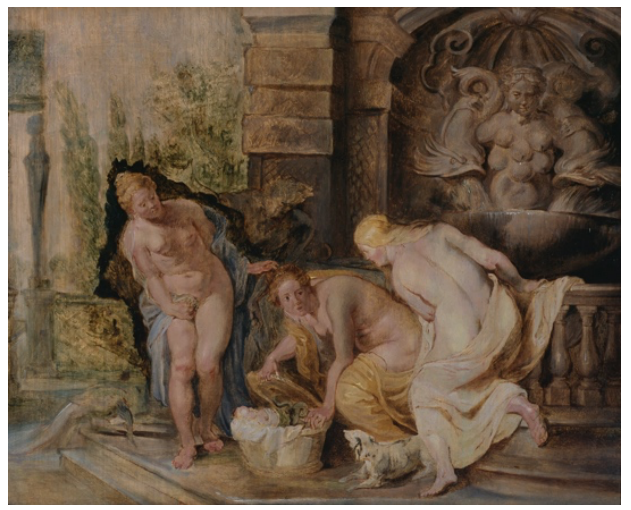

Fig. 15 Peter Paul Rubens, The Discovery of Erichthonius, ca. 1615, oil on panel, $50 \times 41 \mathrm{~cm}$. The Courtauld Gallery of Art, London, The Samuel Courtauld Trust P.1978.PG.364

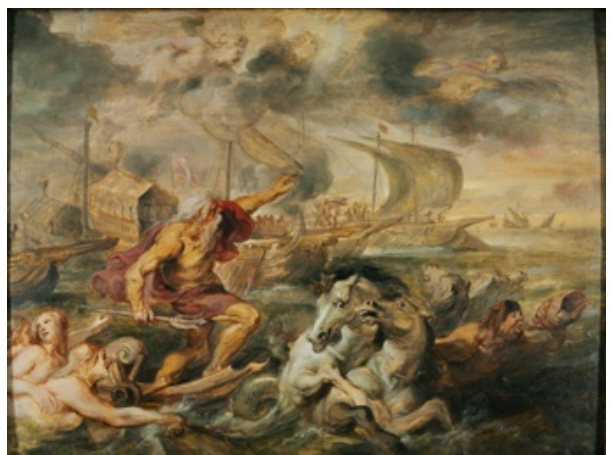

Fig. 3a Peter Paul Rubens, Deucalion and Pyrrha, 1636, oil on panel, 26 x 40.7 cm. Museo del Prado, Madrid, inv. no. 2041 


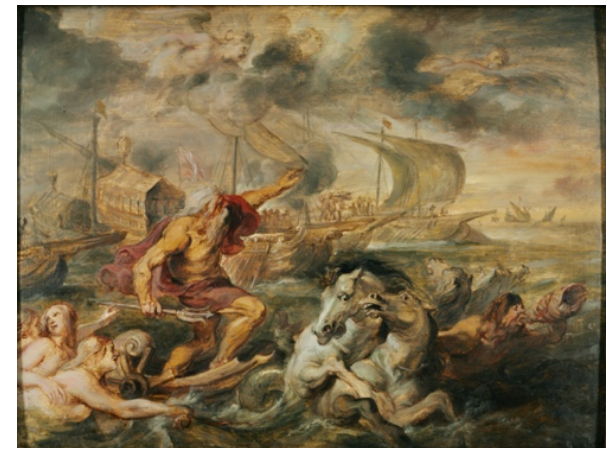

Fig. 16 Peter Paul Rubens, The Voyage of the Cardinal Infante Ferdinand of Spain from Barcelona to Genoa in April 1633, with Neptune Calming the Tempest (Quos ego), 1635, detail (Boreas), oil on panel, $48.9 \times 64.1$ $\mathrm{cm}$. Harvard Art Museums/Fogg Museum, Cambridge, MA, Alpheus Hyatt Purchasing Fund, 1942.174

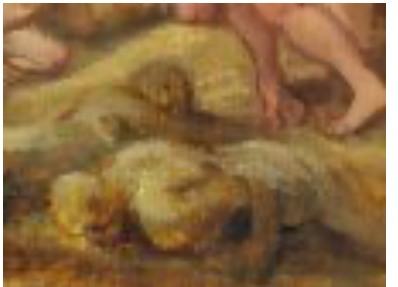

Fig. 17 Peter Paul Rubens, Deucalion and Pyrrha (fig. 3), stages of creation

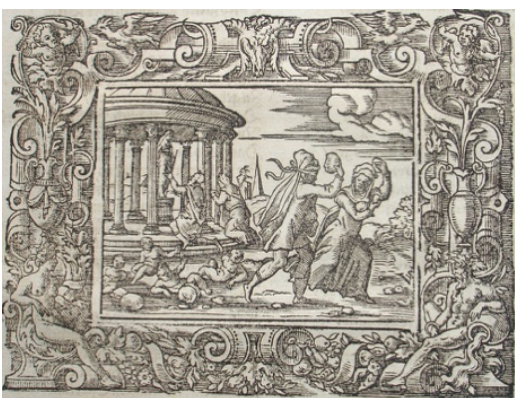

Fig. 18 Virgil Solis after Bernard Salomon, woodcut from Ovid, Metamorphoses (Frankfurt am Main: Feyerabend, 1581), fol. 7v

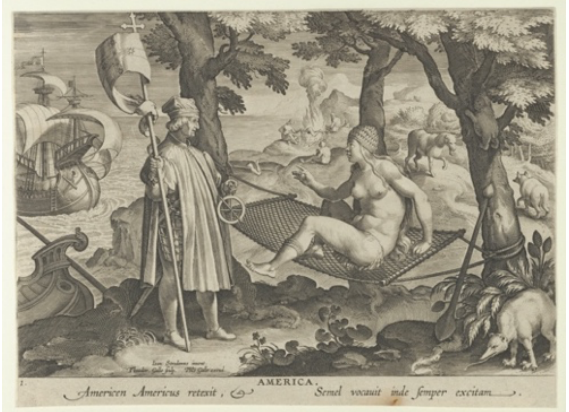

Fig. 19 Theodor Galle after Jan van der Straet, called Stradanus, Allegory of America, ca. 1600, from the Nova Reperta (New Inventions and Discoveries) series, sheet: $28.3 \times 34.6 \mathrm{~cm}$. The Metropolitan Museum of Art, New York, metmuseum.org (artwork in the public domain)

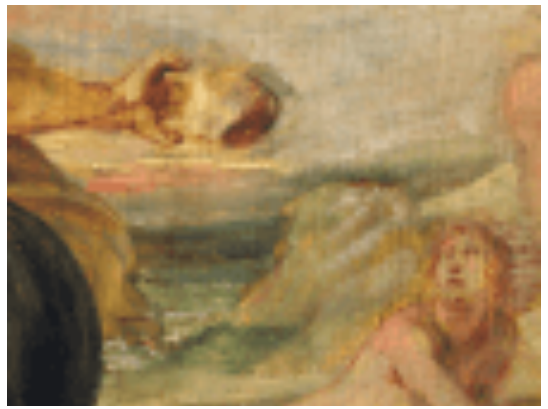

Fig. 20 Peter Paul Rubens, Deucalion and Pyrrha (fig. 3), rock

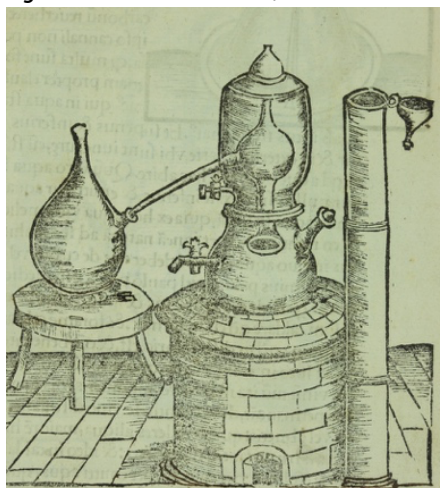

Fig. 21 An alchemical balneum Mariae from Philip Ulstad, Coelum philosophorum (Strasbourg, 1528) (artwork in the public domain)

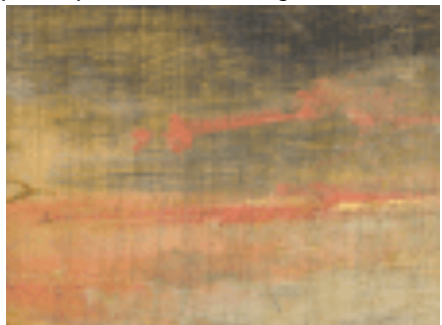

Fig. 22 Peter Paul Rubens, Deucalion and Pyrrha (fig. 3), sky

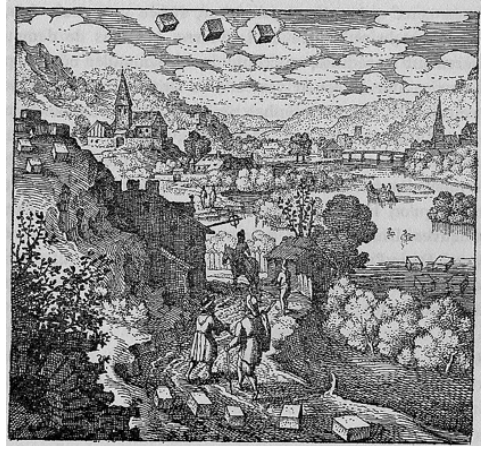

Fig. 23 Matthäus Merian, etching (Emblem 36) in Michael Maier, Atalanta fugiens (Oppenheim, 1618), 153 


\section{Bibliography}

De Acosta, José. Natural and Moral History of the Indies. Edited by Clements R. Markham. Translated by Edward Grimestone. Cambridge: Cambridge University Press, 2010.

Aeschylus. Prometheus Bound. Translated by Janet Case. London: Dent, 1905.

Alberti, Leon Battista. On Painting. Translated by John R. Spencer. New Haven and London: Yale University Press, 1973.

Alpers, Svetlana. The Art of Describing: Dutch Art in the Seventeenth Century. Chicago: University of Chicago Press, 1983.

-. The Decoration of the Torre de la Parada. Corpus Rubenianum Ludwig Burchard 9. London and New York: Phaidon, 1971.

—. The Making of Rubens. New Haven: Yale University Press, 1995.

-. "Manner and Meaning in Some Rubens Mythologies." Journal of the Warburg and Courtauld Institutes 30 (1967): 272-95. Anaf, Willemien, Koen Janssens, and Karolien de Wael.

"Formation of Metallic Mercury during Photodegradation/Photodarkening of $\alpha$ -

HgS: Electrochemical Evidence." Angewandte Chemie International Edition 52, no. 48 (2013): 12568-71.

Baadj, Nadia. Jan van Kessel I (1626-79): Crafting a Natural History of Art in Early Modern Antwerp. London and Turnhout: Harvey Miller, 2016.

Balis, Arnout. "Facetten van de Vlaamse dierenschilderkunst van de 15 de tot de 17 de eeuw." In Het Aards Paradijs: Dierenvoorstellingen in de Nederlanden van de 16de en 17de eeuw, 37-55. Antwerp: Standaard, 1982.

Baltrusaitis, Jurgis. Aberrations: An Essay on the Legend of Forms. Translated by Richard Miller. Cambridge, MA, and London: MIT Press, 1989.

Belkin, Kristin Lohse. Copies and Adaptations from Renaissance and Later Artists. Corpus Rubenianum Ludwig Burchard XXVI, vol. 1. London: Harvey Miller, 2009.

Bellori, Giovanni Pietro. Le Vite de’ pittori, scultori et architetti moderni. Rome, 1672.

-. Vita di Pietro Paolo Rubens \& Vita di Antonio Van Dyck / Das Leben des Peter Paul Rubens \& Das Leben des Anthonis van Dyck. Edited by Fiona Healy. Translated by Anja Brug. Göttingen: Wallstein, 2020. 
Bennett, Jane. Vibrant Matter: A Political Ecology of Things. Durham, NC: Duke University Press, 2009.

Berrie, Barbara H. “Mining for Color: New Blues, Yellows, and Translucent Paint." In Early Modern Color Worlds, edited by Tawrin Baker, Sven Dupré, Sachiko Kusakawa, and Karin Leonhard, 20-46. Leiden and Boston: Brill, 2015.

Berry, Fabio. "'Painting in Stone': Early Modern Experiments in a Metamedium," Art Bulletin 99, no. 3 (July 2017): 30-61.

Bodart, Didier. Rubens e la pittura fiamminga del Seicento nelle collezioni pubbliche fiorentine. Florence: Centro Di, 1977.

Boulboullé, Jenny. "Drawn Up by a Learned Physician from the Mouths of Artisans: The Mayerne Manuscript Revisited." Nederlands Kunsthistorisch Jaarboek 68, no. 1 (2019): 227-29.

Bredekamp, Horst. The Lure of Antiquity and the Cult of the Machine: The Kunstkammer and the Evolution of Nature, Art, and Technology. Translated by Allison Brown. Princeton: Markus Wiener Publishers, 1995.

Caneva, Caterina. La Medusa del Caravaggio Restaurata. Rome: Retablo, 2002.

Cennini, Cennino. Il Libro dell'Arte: A New English Translation and Commentary with Italian Transcription. Translated by Lara Broecke. London: Archetype, 2015.

De Clippel, Karolien. "Vibrant Veils and Daring Draperies: On Rubens's Clothing of Nymphs and Goddesses." In Rubens and the Human Body, edited by Cordula van Wythe, 199-223. Turnhout: Brepols, 2018.

Cody, Steven J. "Rubens and the 'Smell of Stone': The Translation of the Antique and the Emulation of Michelangelo." Arion: A Journal of Humanities and the Classics 20, no. 3 (Winter 2013):39-55.

Cole, Michael. “Cellini’s Blood." Art Bulletin 81, no. 2 (June 1999): 215-35. Conti, Natale. Mythologiae sive explicationum fabularum libri X. Venice, 1567.

Cropper, Elizabeth. "The Petrifying Art: Marino's Poetry and Caravaggio." Metropolitan Museum Journal 26 (1991): 193-212.

Dackerman, Susan, ed. Prints and the Pursuit of Knowledge in Early Modern Europe. New Haven: Yale University Press, 2011.

Daston, Lorraine, and Katherine Park. Wonders and the Order of Nature. New York: Zone Books, 2001. 
Davies, Surekha. Renaissance Ethnography and the Invention of the Human: New Worlds, Maps, and Monsters. Cambridge: Cambridge University Press, 2016.

Didi-Huberman, Georges. "The Art of Not Describing: Vermeer-the Detail and the Patch.” History of the Human Sciences 2 (1989): 135-69.

-. Fra Angelico: Dissemblance and Figuration. Translated by Jane Marie Todd. Chicago: University of Chicago Press, 1995.

Doherty, Tiarna, Mark Leonard, and Jørgen Wadum. "Brueghel and Rubens at Work: Technique and the Practice of Collaboration." In Rubens and Brueghel: A Working Friendship, edited by Anne T. Woollett and Ariane van Sucthelen, 215-51. Zwolle: Waanders, 2006.

Dupré, Sven. Laboratories of Art: Alchemy and Art Technology from Antiquity to the 18th Century. Cham: Springer, 2014.

Van Eck, Caroline. Levende Beelden: Kunst werken en kijken. Leiden and Brussels: Leiden University Press, 2011.

-. "The Petrifying Gaze of Medusa: Ambivalence, Explexis, and the Sublime." Journal of Historians of Netherlandish Art 8, no. 2 (Summer 2016): https://doi.org/10.5092/jhna.2016.8.2.3.

D’Elio, Una Roman. “Tintoretto, Aretino, and the Speed of Creation.” Word \& Image 20 (2004): 206-18.

Esposito, Teresa. “Black Ethiopians and the Origin of 'Materia Prima' in Rubens' Images of Creation." Oud Holland 133, no. 1 (2020): 10-32.

-. "Rubens's Encounter with Natural Philosophy and the 'Occult Sciences' in 17th-century Italy.” In Rubens e la cultura italiana, 1600-1608, edited by Raffaella Morselli and Cecilia Paolini, 233-46. Rome: Viella, 2020.

Faber, Johann. Animalia Mexicana, descriptionibus, scholiisq. axposita. Rome, 1628.

Fehrenbach, Frank. "Calor nativus - Color vitale: Prolegomena zu einer Ästhetik des 'Lebendigen Bildes' in der frühen Neuzeit." In Muster in Wandel: Zur Dynamik topischer Wissensordnungen in Spätmittelalter und Früher Neuzeit, edited by Wolfgang Dickhut, Stefan Manns, and Norbert Winkler, 165-90. Göttingen: V\&R, 2008.

Freedberg, David. The Eye of the Lynx: Galileo, His Friends, and the Beginnings of Modern Natural History. Chicago: University of Chicago Press, 2002. 
-. “The Hand of Rubens.” In Peter Paul Rubens: Paintings and Oil Sketches, 7-25. New York: Gagosian Gallery, 1995.

Gage, John. Color and Culture: Practice and Meaning from Antiquity to Abstraction. Berkeley and Los Angeles: University of California Press, 1993.

Gaudio, Michael. “The Emblem in the Landscape: Matthäus Merian's Etchings for Atalanta fugiens." In Furnace and Fugue: A Digital Edition of Michael Maier's “Atalanta fugiens” (1618) with Scholarly Commentary. Charlottesville: University of Virginia Press, 2020. Digital edition, https://furnaceandfugue.org/essays/gaudio.

Georgievska-Shine, Aneta. "From Ovid's Cecrops to Rubens's City of God in The Finding of Erichthonius." Art Bulletin 86, no. 1 (March 2004): 58-74.

-. Rubens and the Archaeology of Myth, 1610-1620: Visual and Poetic Memory. Surrey: Ashgate, 2009.

Georgievska-Shine, Aneta, and Larry Silver. Rubens, Velázquez, and the King of Spain. Burlington, VT: Ashgate, 2014.

Goesch, Andrea. Diana Ephesia: Ikonographische Studien zur Allegorie der Natur in der Kunst vom 16.-19. Jahrhundert. Frankfurt and New York: Lang, 1996.

Göttler, Christine. “The Alchemist, the Painter, and the 'Indian Bird': Joining Arts and Cultures in Seventeenth-Century Antwerp; Adriaen von Utrecht's Allegory of Fire in the Royal Museum of Fine Arts in Brussels." In Synergies in Visual Culture / Bildkulturen im Dialog (Festschrift for Gerhard Wolf), edited by Manuela de Giorgi, 449-512. Paderborn and Munich: Fink, 2013.

-. “Tales of Transformation: Hendrick Goltzius's 'Allegory of the (Alchemical) Arts' in the Kunstmuseum Basel." 21: Inquiries into Art, History, and the Visual. Heidelberg 1, no. 2 (2020): 404-46, https://doi.org/10.11588/xxi.2020.2.76233.

-. "Vulcan's Forge: The Sphere of Art in Early Modern Antwerp." In Knowledge and Discernment in the Early Modern Arts, edited by Sven Dupré and Christine Göttler, 52-87. London and New York: Routledge, 2017.

Göttler, Christine, Bart Ramakers, and Joanna Woodall, eds. Trading Values in Early Modern Antwerp. Nederlands Kunsthistorisch Jaarboeck 64 (2014): 9-37.

Göttler, Christine, and Tine L. Meganck. "Sites of Art, Nature and the Antique in the Spanish Netherlands." In Embattled Territory: The Circulation of Knowledge in the Spanish Netherlands, edited by Sven Dupré, Bert De Munck, Werner Thomas, and Geert Vanpaemel, 333-69. Ghent: Academia Press, 2016. 
Gregori, Mina, and Ermanno Zoffili, eds. The First Medusa: Caravaggio. Milan: 5 Continents, 2011.

Gruber, Gerlinde, and Petr Tomášek. “Albtraumhaft Schön: Rubens’ Wiener Medusenhaupt trifft auf die Brünner Fassung.” Ansichtssache 23, 3-34. Vienna, Kunsthistorisches Museum, 2018.

Gruber, Gerlinde, Sabine Haag, Stefan Weppelmann, and Jochen Sander, eds. Rubens: Kraft der Verwandlung. Munich: Hirmer, 2017.

Hamann, Byron Ellsworth. “The Mirrors of Las Meninas: Cochineal, Silver, and Clay.” Art Bulletin 92, nos. 1/2 (March-June 2010): 18-20.

Heinen, Ulrich. "Haut und Knochen - Fleisch und Blut: Rubens' Affektmalerei." In Rubens passioni: Kultur der Leidenschaften im Barock, edited by Ulrich Heinen and Andreas Thielemann, 70-109. Göttingen: Vandenhoeck \& Ruprecht, 2001.

- " "Huygens, Rubens and Medusa: Reflecting the Passions in Paintings, with Some Considerations of Neuroscience in Art History." Nederlands Kunsthistorisch Jaarboek 60 (2010): 151-78.

Held, Julius. The Oil Sketches of Peter Paul Rubens: A Critical Catalogue, vol. 1. Princeton, N.J.: Princeton University Press, 1980.

—. "Prometheus Bound.” Philadelphia Museum of Art Bulletin 59, no. 279 (August 1963): 16-32.

-. "Rubens and Aguilonius: New Points of Contact." Art Bulletin 61, no. 2 (June 1979): 263. Honig, Elizabeth. "The Beholder as a Work of Art: A Study in the Location of Value in Seventeenth-Century Flemish Painting." Nederlands Kunsthistorisch Jaarboek 46 (1995): 252-97.

-. Painting and the Market in Early Modern Antwerp. New Haven and London: Yale University Press, 1998.

Van Hoogstraten, Samuel. Inleyding tot de Hooge Schoole der Schilderkonst: Anders de Zichtbaere Werelt. Rotterdam, 1678.

-. Samuel van Hoogstraten's Introduction to the Academy of Painting, Or, the Visible World. Edited by Celeste Brusati. Translated by Jaap Jacobs. Los Angeles: Getty Research Institute, 2021.

Van Hout, Nico. "Functies van doodverf met bijzondere aandacht voor de onderschildering en andere onderliggende Stadia in het Werk van P.P. Rubens." PhD diss., Katholieke Universiteit, Leuven, 2005. 
—. "Meaning and Development of the Ground Layer in Seventeenth-Century Painting." Leids kunsthistorisch jaarboek 11 (1998): 199-225.

Van Hout, Nico, with contributions by Arnous Balis. Rubens Unveiled: Notes on the Master's Painting Techniques; A Catalogue of the Rubens Paintings in the Antwerp Museum. Antwerp: Ludion, 2012.

Jaffé, Michael. "Rubens and Optics: Some Fresh Evidence." Journal of the Warburg and Courtauld Institutes 34 (1971): 362-66. Janson, H. W. “The 'Image Made by Chance' in Renaissance Thought.” In De artibus opuscula XL: Essays in Honor of Erwin Panofsky, edited by Millard Meiss, 54-66. New York: New York University Press, 1961.

Juntunen, Eveliina. Peter Paul Rubens' bildimplizite Kunsttheorie in ausgewählten mythologischen Historien 1611-1618. Petersberg: Michael Imhof, 2005.

Kanz, Roland. Die Kunst des Capriccio: Kreativer Eigensinn in Renaissance und Barock. Munich: Deutscher Kunstverlag, 2002.

Kimball, Fiske. “Rubens’ Prometheus.” Burlington Magazine 94, no. 588 (March 1952): 67-68.

Kinew, Shawon. "Sedlmayr's Mother-of-Pearl: Further Notes on Rubens and Flesh Color." Selva: A Journal of the History of Art 2 (Fall 2020): 88-96.

Knaap, Anna C., and Michael C.J. Putnam, eds. Art, Music, and Spectacle in the Age of Rubens: The Pompa Introitus Ferdinandi. London and Turnhout: Brepols, 2013.

Koslow, Susan. "'How looked the Gorgon then ...': the Science and Poetics of the Head of Medusa by Rubens and Snyders." In Shop Talk: Studies in Honor of Seymour Slive, edited by Cynthia P. Schneider, William W. Robinson, and Alice I. Davies, 147-49. Cambridge, MA: Harvard University Art Museums, 1995.

Leesberg, Marjolein, and Leeflang, Huigen, eds. Hendrick Goltzius. The New Hollstein Dutch and Flemish Etchings, Engravings and Woodcuts, 1450-1700, vol. 3. Ouderkerk aan den Ijssel: Sound and Vision, 2012.

-. Stradanus. The New Hollstein Dutch and Flemish Etchings, Engravings and Woodcuts, 1450-1700, vol. 3. Ouderkerk aan den Ijssel: Sound and Vision, 2008.

Leinkauf, Thomas. "Implikationen des Begriffs natura naturans in der frühen Neuzeit." In Ludi Naturae: Spiele der Natur in Kunst und Wissenschaft, edited by Natascha Adamowsky, Hartmut Böhme, and Robert Felfe, 103-18. Munich: Wilhelm Fink, 2011.

Leonhard, Karin. Bildfelder: Stilleben und Naturstücke des 17. Jahrhunderts. Berlin: Akademie, 2013. 
-. "Painted Poison: Venomous Beasts, Herbs, Gems, and Baroque Color Theory." Nederlands Kunsthistorisch Jaarboek 61 (2011): 116-47.

-. "Pictura's Fertile Field: Otto Marseus van Schrieck and the Genre of Sottobosco Painting." Simiolus 31, no. 2 (2010): 95-118.

-. “'The various natures of middling colours we may learne of painters': Sir Kenelm Digby Looks at Rubens and Van Dyck." In Knowledge and Discernment in the Early Modern Arts, edited by Sven Dupré and Christine Göttler, 163-85. London and New York: Routledge, 2017.

Long, Pamela. Artisan/Practitioners and the Rise of the New Sciences, 1400-1600. Corvallis, OR: Oregon State University Press, 2011.

Magurn, Ruth. The Letters of Peter Paul Rubens. Cambridge, MA: Harvard University Press, 1955.

Mainz, Valerie, and Emma Stafford, eds. The Exemplary Hercules from the Renaissance to the Enlightenment and Beyond. Leiden and Boston: Brill, 2020. Marino, Giambattista. La Galeria. Trento: La finestra, 2005.

McGrath, Elizabeth. "Garlanding the Great Mother: Rubens, Jan Brueghel and the Celebration of Nature's Fertility." In Munuscula amicorum: Contributions on Rubens and his Colleagues in Honour of Hans Vlieghe, edited by Katlijne van der Stighelen, 1:130-22. Turnhout: Brepols, 2006.

-. "Rubens's Arch of the Mint." Journal of the Warburg and Courtauld Institutes 37 (1974): 196.

-. "Rubens and Ovid." In The Afterlife of Ovid, 159, edited by Peter Mack and John North. London: Institute of Classical Studies 2015.

McGrath, Elizabeth, and Bert Schepers, eds. Rubens, Mythological Subjects: Achilles to the Graces. Corpus Rubenianum Ludwig Burchard, XI, vol. 1. London and Turnhout: Harvey Miller, 2016.

Van der Meulen, Marjon. Copies after the Antique. Corpus Rubenianum Ludwig Burchard 23. London: Harvey Miller, 1993.

Miedema, Hessel. "Over kwaliteitsvoorschriften in het St. Lucasgilde, over 'doodverf."' Oud Holland 101 (1987): 141-47.

Meganck, Tine L. “The 'Reddener': Peter Paul Rubens and Alchemy.” In Art and Alchemy: The Mystery of Transformation, edited by Sven Dupré, Dedo von Kerssenbrock-Krosigk, and Beat Wismer, 146-55. Munich: Hirner, 2014. 
-. "Rubens on the Human Figure: Theory, Practice and Metaphysics." In Rubens: A Genius at Work, edited by Michel Draguet and Joost Vander Auwera, 52-64. Tielt: Lannoo, 2007.

Ovid, and A.S. Kline. The Metamorphoses of Ovid. 2000.

https://ovid.lib.virginia.edu/trans/Ovhome.html

Parkhurst, Charles. "Aguilonius' Optics and Rubens' Color." Nederlands Kunsthistorisch Jaarboek 12 (1961): 35-48.

Pfisterer, Ulrich. Kunst-Geburten: Kreatitivät, Erotik, Körper in der Frühen Neuzeit. Berlin: Wagenbach, 2014.

De Piles, Roger. Cours de peinture par principes. Paris, 1708.

Philips, Elena. Cochineal Red: The Art History of a Color. New York: Metropolitan Museum of Art, 2010.

Posèq, Avigdor. “Caravaggio's Medusa Shield." Gazette des Beaux-Arts 6, no. 113 (1989): 17074.

Prohaska, Wolfgang. "Das Haupt der Medusa." In Das Flämische Stilleben 1550-1680: Eine Ausstellung des Kunsthistorischen Museums Wien und der Kulturstiftung Ruhr Essen, edited by Christa Nitze-Ertz, Ute Kleinmann, and Stephan Brakensiek, 58-9. Lingen: Luca, 2002.

Raggio, Olga. "The Myth of Prometheus: Its Survival and Metamorphoses up to the Eighteenth Century." Journal of the Warburg and Courtauld Institutes 21, no. 1/2 (1958): 44-62.

Rooses, Max. Rubens. Translated by Harold Child. London: Duckworth, 1904. Rosenberg, Jakob. "Rubens's Sketch for The Wrath of Neptune." Bulletin of the Fogg Museum of Art 10, no. 1 (November 1942): 10-11.

Rosenthal, Lisa. "Manhood and Statehood: Rubens's Construction of Heroic Virtue." Oxford Art Journal 16, no. 1 (1993): 92-95.

Sandrart, Joachim von. Teutsche Akademie. Frankfurt, 1675.

Seeling, Gero. “Die Macht der Kunst: Peter Paul Rubens." In Die Menagerie der Medusa: Otto Marseus van Schrieck und die Gelehrten, edited by Gero Seeling, 42-45. Schwerin: Hirmer, 2017.

Shawe-Taylor, Desmond, and Scott, Jennifer, eds. Bruegel to Rubens: Masters of Flemish Painting. London: Royal Collection Publications, 2007. 
Smith, Pamela H. The Body of the Artisan: Art and Experience in the Scientific Revolution. Chicago and London: University of Chicago Press, 2004.

—. "Vermilion, Mercury, Blood, and Lizards: Matter and Meaning in Metalworking." In Materials and Expertise in Early Modern Europe: Between Market and Laboratory, edited by Ursula Klein and E. C. Spary, 29-48. Chicago and London: University of Chicago Press, 2010. Smith, Pamela H., and Tonny Beentjes. "Nature and Art, Making and Knowing: Reconstructing Sixteenth-Century Life-Casting Techniques.” Renaissance Quarterly 63, no. 1 (Spring 2020): 128-79.

Sparti, Donatella. "Bellori's Biography of Rubens: An Assessment of Its Reliability and Sources." Simiolus 36, nos. 1/2 (2012): 85-102. Stechow, Wolfgang. "The Finding of Erichthonius: An Ancient Theme in Baroque Art." In Latin American Art, and the Baroque Period in Europe, 2735. Studies in Western Art 3. Princeton: Princeton University Press, 1963.

Suda, Sasha, and Kirk Nickel, eds. Early Rubens. Munich/London/New York: Delmonico Books/Prestel, 2019.

Suthor, Nicola. “Transparenz der Mittel: Zur Sichtbarkeit der Imprimatur in einigen Werken Rembrandts." In Der Grund: Das Feld des Sichtbaren, edited by Gottfried Böhm, 223-50. Munich: Fink, 2012.

Sutton, Peter C. “The Head of Medusa.” In The Age of Rubens, edited by Peter C. Sutton, 245-47. Gent: Ludion, 1993.

Thielemann, Andreas. "Peter Paul Rubens (1577-1640), De imitatione statuarum." In Abgekupfert: Roms Antiken in den Reproduktionsmedien der Frühen Neuzeit; Katalog zur Aussellung Kunstsammlung der Gipsabgüsse, edited by Manfred Luchterhandt, Lisa Roemer, Johannes Bergemann, and Daniel Graepler, 319-21. Petersberg: Michael Imhof, 2014.

-. Rubens' Traktat De imitatione statuarum.” In Imitatio als Transformation: Theorie und Praxis der Antikennachahmung in der Frühen Neuzeit, edited by Ursula Rombach and Peter Seiler, 95-150. Petersberg: Michael Imhof, 2012.

Thijs, Alfons K. L., ed. Prosper Arents: De Bibliotheek van Pieter Paul Rubens: Een reconstructive. Antwerp: Vereniging der Antwerpse Bibliofielen, 2001.

Vasari, Giorgio. The Lives of the Most Eminent Painters, Sculptors, and Architects. Translated by Gaston du C. De Vere. London: Macmillan and Co. Ld. \& The Medici Society, 1912-14.

—. Le Vite de' piu eccellenti pittori, scultori, et architettori. Florence, 1568. 
Vermeylen, Filip. “The Colour of Money: Dealing in Pigments in Sixteenth-Century Antwerp.” In Trade in Artists' Materials: Markets and Commerce in Europe to 1700, edited by Jo Kirby, Susie Nash, and Joanna Cannon, 356-65. London: Archetype, 2010.

Vernant, Jean-Pierre. “In the Mirror of the Medusa." In The Medusa Reader, edited by Marjorie Garber and Nancy J. Vickers, 200-31. New York: Routledge, 2003.

Weststeijn, Thijs. "Painting's Enchanting Poison: Artistic Efficacy and the Transfer of Spirits." In Spirits Unseen: The Representation of Subtle Bodies in Early Modern European Culture, edited by Christine Göttler and Wolfgang Neuber, 141-77. Leiden and Boston: Brill, 2007.

Wood, Jeremy. Rubens: Copies and Adaptations from Renaissance and Later Masters: Italian Artists. 2, Titian and North Italian Art. Corpus Rubenianum Ludwig Burchard 26. London: Harvey Miller, 2010.

Woollett, Anne T., and Ariane van Sucthelen, eds. Rubens and Brueghel: A Working Friendship. Zwolle: Waanders, 2006.

Worp, S. A. “Constantijn Huygens over de schilders van zijn tijd.” Oud Holland 9 (1891): 10636. Zorach, Rebecca. Blood, Milk, Ink, Gold: Abundance and Excess in the French Renaissance. Chicago: University of Chicago Press, 2005.

\section{Endnotes}

Unless otherwise stated, the translations are those of the author.

1. Giovanni Pietro Bellori, "Vita di Pietro Paolo Rubens," in Le Vite de' pittori, scultori et architetti moderni (Rome, 1672), 246.

2. Rubens and his brother Philip were the first to Latinize their family name, which can be traced as early as 1396 and was originally spelled "Rubbens" or "Ruebens"; Max Rooses, trans. Harold Child, Rubens (London: Duckworth, 1904), 1:2-3.

3. 3On Rubens's "physiology of painting" and the emerging recognition of the circulation of the blood codified in the work of William Harvey, see Ulrich Heinen, "Haut und Knochen Fleisch und Blut: Rubens' Affektmalerei," in Ulrich Heinen and Andreas Thielemann, eds., Rubens passioni: Kultur der Leidenschaften im Barock (Göttingen: Vandenhoeck \& Ruprecht, 2001), 70-109. Julius Held argued that Rubens styled himself as a person of sanguine temperament; "Rubens and Aguilonius: New Points of Contact," Art Bulletin 61, no. 2 (June 1979): 263.

4. 4The first to reproduce the actual inscription on Rubens's tomb was his French biographer Roger de Piles, as Donatella Sparti notes in her analysis of Bellori's sources: "Bellori's Biography of Rubens: An Assessment of Its Reliability and Sources,” Simiolus 36, no.1/2 (2012): 87.

5. For a short list of such interpretations of Rubens's paintings, see the extensive footnote on the epitaph in the Italian-German edition of Bellori, Vita di Pietro Paolo Rubens \& Vita di 
Antonio Van Dyck / Das Leben des Peter Paul Rubens \& Das Leben des Anthonis van Dyck, ed. Fiona Healy, trans. Anja Brug (Göttingen: Wallstein, 2020), 110n302. As Christine Göttler notes, "Rubens was aware of the painterly and alchemical associations his name carried. The reddening sky in his self-portraits for Nicolas-Claude Fabri de Peiresc (15801637 ) and Charles I as well as the aurora borealis in the Mantuan Self-Portrait in a Circle of Friends may be seen as playing on the color associations of his name and the enlivening and transformational qualities of his art"; Christine Göttler, "Vulcan's Forge: The Sphere of Art in Early Modern Antwerp," in Knowledge and Discernment in the Early Modern Arts, ed. Sven Dupré and Christine Göttler (London and New York: Routledge, 2017), 53. Tine L. Meganck discusses the alchemical significance of Rubens's name in “The 'Reddener': Peter Paul Rubens and Alchemy," in Art and Alchemy: The Mystery of Transformation, ed. Sven Dupré, Dedo von Kerssenbrock-Krosigk, and Beat Wismer, trans. Susanna Michael (Munich: Hirner, 2014), 147.

6. Bellori, "Vita di Pietro Paolo Rubens," 247.

7. Samuel van Hoogstraten, Inleyding tot de Hooge Schoole der Schilderkonst: Anders de Zichtbaere Werelt (Introduction to the Academy of Painting: Or, the Visible World) (Rotterdam, 1678), 217. See also Celeste Brusati, ed., Samuel van Hoogstraten's Introduction to the Academy of Painting, Or, the Visible World, trans. Jaap Jacobs (Los Angeles: Getty Research Institute, 2021). Christine Göttler has written extensively on the analogies between color and fire in late sixteenth- and early seventeenth-century Antwerp painting. On the notion of "living color," heat, and the early modern aesthetic of living images, see Frank Fehrenbach, "Calor nativus - Color vitale: Prolegomena zu einer Ästhetik des 'Lebendigen Bildes' in der frühen Neuzeit," in Muster in Wandel: Zur Dynamik topischer Wissensordnungen in Spätmittelalter und Früher Neuzeit, ed. Wolfgang Dickhut, Stefan Manns, and Norbert Winkler (Göttingen: V\&R, 2008), 165-90.

8. With this term I refer to the work of political theorist Jane Bennett and her book Vibrant Matter: A Political Ecology of Things (Durham, NC: Duke University Press, 2009). [ii] The seventeenth-century debates on spontaneous generation are summarized in relation to painting in Karin Leonhard, Bildfelder: Stilleben und Naturstücke des

17. Jahrhunderts (Berlin: Akademie, 2013), 61-69.

9. The seventeenth-century debates on spontaneous generation are summarized in relation to painting in Karin Leonhard, Bildfelder: Stilleben und Naturstücke des 17. Jahrhunderts (Berlin: Akademie, 2013), 61-69.

10. On the opposition of natura naturans and natura naturata, see Thomas Leinkauf, "Implikationen des Begriffs natura naturans in der frühen Neuzeit," in Natascha Adamowsky, Hartmut Böhme, and Robert Felfe, eds., Ludi Naturae: Spiele der Natur in Kunst und Wissenschaft (Munich: Wilhelm Fink, 2011), 103-18.

11. On the Paracelsan tradition and the rise of early modern chemistry, see the summary of literature in Thijs Weststeijn, "Painting's Enchanting Poison: Artistic Efficacy and the Transfer of Spirits," in Spirits Unseen: The Representation of Subtle Bodies in Early Modern European Culture, ed. Christine Göttler and Wolfgang Neuber (Leiden and Boston: Brill, 2007), 149n37.

12. Leonhard, Bildfelder, 104. 
13. Jan van Eyck's (1390-1441) legendary “invention" of oil painting was characterized by Vasari and Karel van Mander as a secret alchemical breakthrough. On alchemy, art, and technology in the early modern Low Countries, see Sven Dupré, Laboratories of Art: Alchemy and Art Technology from Antiquity to the 18th Century (Cham: Springer, 2014); and Dupré, von Kerssenbrock-Krosigk, and Wismer, eds., Art and Alchemy. For a recent case study of painting and alchemy in the seventeenth-century Dutch Republic, see Elisabeth Berry Drago, Painted Alchemists: Early Modern Artistry and Experiment in the Work of Thomas Wijck (Amsterdam: Amsterdam University Press, 2019). Spontaneous generation, alchemy, and oil painting are explored in depth in Leonhard, Bildfelder. For a broader theoretical discussion of painting and alchemy, see James Elkins, What Painting Is: How to Think About Oil Painting Using the Language of Alchemy (New York: Routledge, 2000).

14. See Christine Göttler, “Tales of Transformation: Hendrick Goltzius's 'Allegory of the (Alchemical) Arts' in the Kunstmuseum Basel," 21: Inquiries into Art, History, and the Visual 21: Inquiries into Art, History, and the Visual. Heidelberg 1, no. 2 (2020): 40446, HTTPS://DOI.ORG/10.11588/XXI.2020.2.76233; Christine Göttler, "The Alchemist, the Painter, and the 'Indian Bird': Joining Arts and Cultures in Seventeenth-Century Antwerp; Adriaen von Utrecht's Allegory of Fire in the Royal Museum of Fine Arts in Brussels," in Synergies in Visual Culture / Bildkulturen im Dialog (Festschrift for Gerhard Wolf), ed. Manuela de Giorgi (Paderborn and Munich: Fink, 2013), 449-512; Göttler, "Vulcan's Forge"; and Christine Göttler and Tine L. Meganck, "Sites of Art, Nature and the Antique in the Spanish Netherlands," in Embattled Territory: The Circulation of Knowledge in the Spanish Netherlands, ed. Sven Dupré, Bert De Munck, Werner Thomas, and Geert Vanpaemel (Ghent: Academia Press, 2016), 333-69. See also Leonhard, Bildfelder; and Karin Leonhard, “'The various natures of middling colours we may learne of painters': Sir Kenelm Digby Looks at Rubens and Van Dyck," in Dupré and Göttler, Knowledge and Discernment, 163-85. I take the phrase "the meaning of matter" from historian of science Pamela Smith, whose scholarship has helped initiate many inquiries into artisanal cultures in the early modern Low Countries; Pamela Smith, "Vermilion, Mercury, Blood, and Lizards: Matter and Meaning in Metalworking," in Materials and Expertise in Early Modern Europe: Between Market and Laboratory, ed. Ursula Klein and E. C. Spary (Chicago and London: University of Chicago Press, 2010), 31. For a study of concepts of materiality and generative nature in sixteenth-century France, see Rebecca Zorach, Blood, Milk, Ink, Gold: Abundance and Excess in the French Renaissance (Chicago: University of Chicago Press, 2005).

15. Esposito has connected Rubens's depictions of Black satyrs to Paracelsan notions of prime matter and its role in cosmological and alchemical creation: Teresa Esposito, "Black Ethiopians and the Origin of 'Materia Prima' in Rubens' Images of Creation," Oud Holland 133, no. 1 (2020): 10-32. See also Teresa Esposito, "Rubens's Encounter with Natural Philosophy and the 'Occult Sciences' in 17th-century Italy," in Rubens e la cultura italiana, 1600-1608, ed. Raffaella Morselli and Cecilia Paolini (Rome: Viella, 2020), 233-46. On Paracelsan alchemical imagery originally contained in Rubens's theoretical notebook, see Meganck, “The 'Reddener.” Ulrich Heinen has shown the relationship between 
Rubens's painting techniques, seventeenth-century anatomical theory, and Paracelsan notions of creation; see Heinen, "Haut und Knochen."

16. Esposito, "Black Ethiopians," 11.

17. On this oil sketch, see Julius Held, The Oil Sketches of Peter Paul Rubens: A Critical Catalogue (Princeton, N.J.: Princeton University Press, 1980), cat. no. 194, 1:279-80; Vincent Ducourau, ed., Musée Bonnat, Bayonne (Paris: Réunion des musées nationaux, 2004), 60-61; Arnauld Brejon de Lavergnée, ed., Rubens, exh. cat. (Paris: Éditions de la Réunion des Musées, 2004), cat. no. 91; and Michael Jaffé, "Esquisses inédites de Rubens pour La Torre della Parada," La Revue du Louvre et des Musée de France 14, no. 6 (January 1964): 316. On the function of the scene in the Torre de la Parada cycle, see Svetlana Alpers, The Decoration of the Torre de la Parada, Corpus Rubenianum Ludwig Burchard 9 (London and New York: Phaidon, 1971), no. 31a, 221-22; and Aneta Georgievska-Shine and Larry Silver, Rubens, Velázquez, and the King of Spain (Burlington, VT: Ashgate, 2014), 33-36.

18. Julius Pollux, Onomasticon 1, 47.

19. The extraction of Tyrian purple from mollusks is discussed in Pliny the Elder, Historia naturalis 9, chapters 60-65. On Tyrian purple in Roman antiquity, see John Gage, Color and Culture: Practice and Meaning from Antiquity to Abstraction (Berkeley and Los Angeles: University of California Press, 1993), 25-26.

20. As Held points out, Blaise de Vigenère, in his commentary on the 1614 French translation of Philostratus that may have been Rubens's source, uses purple and red interchangeably ("les Pourpes ou Escarlattes anciennes"): Held, Oil Sketches, 1:279; Philostratus, Imagines (Paris, 1614), 242.

21. Alpers, Torre de la Parada, 222: "The reason for the inclusion of this very unusual scene in the Torre series is not clear."

22. Held (Oil Sketches, 1:280) identifies the painter of Hercules and Iole as Santi di Tito (15361603); see also Georgievska-Shine (Rubens, Velázquez and the King of Spain, 32), as well as Vasari.

23. On Rubens's copies after the Farnese Hercules, see Marjon van der Meulen, Copies after the Antique, Corpus Rubenianum Ludwig Burchard 23 (London: Harvey Miller, 1993), cat. nos. 31, 37, 43, 44; and Valerie Mainz and Emma Stafford, The Exemplary Hercules from the Renaissance to the Enlightenment and Beyond (Leiden and Boston: Brill, 2020), 11-14. On Rubens's Drunken Hercules, see Lisa Rosenthal, "Manhood and Statehood: Rubens's Construction of Heroic Virtue," Oxford Art Journal 16, no. 1 (1993): 92-95.

24. Held, Oil Sketches, 1:280.

25. Held, Oil Sketches, 1:280.

26. Aneta Georgievska-Shine, Rubens, Velázquez, and the King of Spain, 33-36.

27. Museo del Prado, acc. no. P001845. I thank Felipe Pereda for encouraging me to take into account the significance of the sketch's ultimate Spanish audience.

28. On the colorants used by Rubens, whose raw materials included all of the ones in this list, see Nico Van Hout with contributions by Arnout Balis, Rubens Unveiled: Notes on the Master's Painting Techniques; A Catalogue of the Rubens Paintings in the Antwerp Museum (Antwerp: Ludion, 2012), 52-54. For a discussion of the "materiality of color" in early modern visual culture with a summary of the literature, see Barbara H. Berrie, 
"Mining for Color: New Blues, Yellows, and Translucent Paint," in Early Modern Color Worlds, ed. Tawrin Baker et al (Leiden and Boston: Brill, 2015), 22-24.

29. The most convincing date range for both versions remains the one established by Susan Koslow, "'How looked the Gorgon then ...': the Science and Poetics of the Head of Medusa by Rubens and Snyders," in Cynthia P. Schneider, William W. Robinson, and Alice I. Davies, eds., Shop Talk: Studies in Honor of Seymour Slive (Cambridge, MA: Harvard University Art Museums, 1995), 147-49. The Brno version is dated to ca. 1617-18 in Corrinne Chong and Petr Tomášek, "Head of Medusa," in Early Rubens, ed. Sasha Suda and Kirk Nickel, exh. cat. (Munich-London-New York: Delmonico Books/Prestel, 2019), 24449. The Vienna version is likewise dated to $1617 / 18$ by Gerlinde Gruber in "Medusa Inbegriff der Verwandlung," in Rubens: Kraft der Verwandlung, ed. Gerlinde Gruber, Sabine Haag, Stefan Weppelmann, and Jochen Sander, exh. cat. (Munich: Hirmer, 2017), 266-71, cat. no. 119.

30. Long considered an inferior copy, the Brno version was recently identified by Gero Seeling as an original by Rubens and, moreover, as probably the earlier of the two versions; "Die Macht der Kunst: Peter Paul Rubens," in Gero Seelig, Die Menagerie der Medusa: Otto Marseus van Schrieck und die Gelehrten (Schwerin: Hirmer, 2017), 42-45. For a comparative study of the two versions, see also Gerlinde Gruber and Petr Tomášek, “Albtraumhaft Schön: Rubens' Wiener Medusenhaupt trifft auf die Brünner Fassung," Ansichtssache 23 (Vienna, Kunsthistorisches Museum, 2018), 3-34, esp. 28 on the scaled-down copy of the painting signed by Rubens's student Victor Wolfvoet (1612-1652).

31. Lucan, Pharsalia 9.720. The generation of snakes from the Medusa's blood is also mentioned in Ovid, Metamorphoses 4.846-50.

32. Including, as Michael Cole has argued, Cellini's bronze Perseus, which Rubens had seen; Michael Cole, “Cellini’s Blood," Art Bulletin 81, no. 2 (June 1999): 215-35.

33. An attribution of the still life to Snyders is broadly accepted on stylistic and documentary grounds. The inventory of George Villiers (1592-1628), from which the Vienna version was auctioned off in 1635, names the painters as Rubens and "Subter," most likely a misspelling of Snyders's name. Rubens and Snyders are named as the artists in the inventory of Nicolas Sohiers: Gemeentearchif Amsterdam, inv. no. 232, 9.9.1642, no. 28: "eein dito synde een medusa van Rubens en Snyers" (cited in Grüber and Tomášek, “Albtraumhaft Schön,” 32). Previous attributions to Paul de Vos (in Sylvia Ferino-Pagden, Wolfgang Prohaska, and Karl Schütz, eds., Die Gemäldegalerie des Kunsthistorisches Museums in Wien: Verzeichnis der Gemälde\{Vienna: Christian Brandstätter, 1991\}, cat. no. 404) and Jan Brueghel the Elder (Max Rooses, L'Oeuvre de P. P. Rubens: Histoire et Description de ses Tableaux et Dessins \{Antwerp: J. Maes, 1886-92\}, 3:636) are to be considered obsolete, as is Wolfgang Prohaska's suggestion that Rubens executed the still life himself; see Wolfgang Prohaska, "Das Haupt der Medusa," in Das Flämische Stillleben 1550-1680: Eine Ausstellung des Kunsthistorischen Museums Wien und der Kulturstiftung Ruhr Essen, ed. Christa Nitze-Ertz, Ute Kleinmann, and Stephan Brakensiek (Lingen: Luca, 2002), cat. no. 12: 58.

34. Miniaturized copies of the snakes from Head of Medusa appear in Jan van Kessel's (16261679) Four Parts of the World series (1660s); two of the snakes appear in the panel labeled "Angola" and another in "Mecca." See Nadia Baadj, Jan van Kessel I (1626-79): Crafting a Natural History of Art in Early Modern Antwerp (London and Turnhout: Harvey Miller, 
2016), 125-7. Didier Bodart links Van Kessel's visual citation of the snakes to his unusual signature, composed of various insects; Rubens e la pittura fiamminga del Seicento nelle collezioni pubbliche fiorentine (Florence: Centro Di, 1977), 306. Indeed, the "Angola" panel appears directly beneath Kessel's signature. On the animals in Rubens and Snyders's painting, see especially Arnout Balis, "Facetten van de Vlaamse dierenschilderkunst van de 15 de tot de 17de eeuw," in Het Aards Paradijs: Dierenvoorstellingen in de Nederlanden van de 16de en 17de eeuw, exh. cat. (Antwerp: Standaard, 1982), 37-55, 44-45; and Peter C. Sutton, "The Head of Medusa," in The Age of Rubens, exh. cat. (Gent: Ludion, 1993), 2:247.

35. Pliny, Natural History 38, 8, 85.

36. Mentioned in Lucan's text, the amphisbaena was also described in Johann Faber's Animalia Mexicana (Rome, 1628), a work that mentions Rubens and his brother by name; Esposito, "Black Ethiophians," 10. On the "Mexican amphisbaena," see David Freedberg, The Eye of the Lynx: Galileo, His Friends, and the Beginnings of Modern Natural History (Chicago: University of Chicago Press, 2002), 261, 291-292, 361-364. On the amphisbaena as possibly reflecting a lost source shared with a later illustration in Francisco Hernandez's (15171587) Rerum medicarum Novae Hispaniae thesaurus (Rome 1651), a project in which Faber also took part, see Gruber and Tomášek, "Albtraumhaft Schön,” 11.

37. On this painting, see Desmond Shawe-Taylor and Jennifer Scott, eds., Bruegel to Rubens: Masters of Flemish Painting (London: Royal Collection Publications, 2007), no. 25, 126-29.

38. A second, earlier version of Caravaggio's Head of Medusa, dated to 1596 and now in a private collection, was brought to light about a decade ago; see Mina Gregori and Ermanno Zoffili, eds., The First Medusa: Caravaggio (Milan: 5 Continents, 2011). On the Uffizi version, which dates to 1597, see Caterina Caneva, La Medusa del Caravaggio Restaurata (Rome: Retablo, 2002); and Avigdor Posèq, "Caravaggio's Medusa Shield," Gazette des Beaux-Arts 6, no. 113 (1989): 170-74.

39. Giambattista Marino's ekphrasis on Caravaggio's Medusa, published in his collection La galeria (Venice: Ciotti, 1619-20), emphasizes the painting's ability to turn enemies into stone; addressing the work's first owner, the Grand Duke of Tuscany, Marino concludes "ché la vera Medusa è il valor vostro" (that the true Medusa is your valor); Marino, $\mathrm{La}$ galeria 1:32. On Marino's poem, see Elizabeth Cropper, “The Petrifying Art: Marino's Poetry and Caravaggio,” Metropolitan Museum Journal 26 (1991), 204.

40. See Ulrich Heinen, "Huygens, Rubens and Medusa: Reflecting the Passions in Paintings, with Some Considerations of Neuroscience in Art History," Nederlands Kunsthistorisch Jaarboek 60 (2010): 151-78.

41. Heinen, "Huygens, Rubens and Medusa." The evidence that the painting was kept behind a comes from a description by Constantijn Huygens (1597-1687), who saw a version of the work, probably identical with the one today in Brno, at Sohier's Amsterdam home; S. A. Worp, "Constantijn Huygens over de schilders van zijn tijd," Oud Holland 9 (1891): 10636.

42. Heinen, "Huygens, Rubens and Medusa." On Rubens and the early modern concept of emotion known as the passions, see Heinen and Thielemann, Rubens passioni, esp. 70-109.

43. In this sense, the curtain could also be interpreted as the allegorical veil of nature Rubens also depicts in Nature Adorned (ca. 1615; Kelvingrove Art Gallery and Museum, Glasgow) a collaboration with Jan Brueghel the Elder (1528-1625). On this latter painting as an 
allegory of nature's secrets, see Esposito, "Black Ethiopians," 15-16; and Elizabeth McGrath, "Garlanding the Great Mother: Rubens, Jan Brueghel and the Celebration of Nature's Fertility," in Munuscula amicorum: Contributions on Rubens and his Colleagues in Honour of Hans Vlieghe, ed. Katlijne van der Stighelen, 2 vols. (Turnhout: Brepols, 2006), 1:103-22. On Rubens's veils, see Karolien de Clippel, “Vibrant Veils and Daring Draperies: On Rubens's Clothing of Nymphs and Goddesses," in Rubens and the Human Body, ed. Cordula van Wythe (Turnhout: Brepols, 2018), 199-223, esp. 26 on Nature Adorned.

44. The frontality of the head of Medusa was traditionally a crucial aspect of its horror. JeanPierre Vernant, "In the Mirror of the Medusa" (1985), in The Medusa Reader, ed. Marjorie Garber and Nancy J. Vickers (New York: Routledge, 2003), 200-31; and Frontisi-Ducroix, trans. Seth Graebner, "The Gorgon, Paradigm of Image Creation," in The Medusa Reader, 263.

45. On the sottobosco genre, see Leonhard, Bildfelder; Karin Leonhard, "Painted Poison: Venomous Beasts, Herbs, Gems, and Baroque Color Theory," Nederlands Kunsthistorisch Jaarboek 61 (2011): 116-47; and Karin Leonhard, "Pictura's Fertile Field: Otto Marseus van Schrieck and the Genre of Sottobosco Painting," Simiolus 31, no. 2 (2010): 95-118. See also Susanna Steensma, Otto Marseus van Schrieck: Leben und Werk, Studien zur Kunstgeschichte 131 (Hildesheim/Zürich/New York: Olms, 1999).

46. A connection between Rubens and Snyders's painting and this later genre is evidenced by an anonymous Flemish painting in the Uffizi, previously misattributed to Leonardo da Vinci, which depicts the head of Medusa in a grotto inhabited by chthonic creatures. On this work and its unresolved relationship to the sottobosco genre and to Rubens and Snyders's painting, see Leonhard, Bildfelder, 182-83; Seelig, Die Menagerie der Medusa, 4345; and Gruber and Tomášek, "Albtraumhaft Schön,” 16.

47. On sottobosco paintings as a form of "negative mimesis," see Leonhard, Bildfelder, 100. On the early modern analogies between image-making and sexual reproduction, see Ulrich Pfisterer, Kunst-Geburten: Kreatitivät, Erotik, Körper in der Frühen Neuzeit (Berlin: Wagenbach, 2014).

48. On nature printing in the sottoboschi, see Leonhard, Bildfelder, 30-33.

49. See Pamela H. Smith and Tonny Beentjes, "Nature and Art, Making and Knowing: Reconstructing Sixteenth-Century Life-Casting Techniques," Renaissance Quarterly 63, no. 1 (Spring 2020): 128-79. On examples of life casts of lizards by Wenzel Jamnitzer and from the workshop of Bernard Palissy, see Leonhard, Bildfelder, 100.

50. Koslow, "How Looked the Gorgon Then," 147.

51. On Rubens's Paracelsan interests, see Esposito, "Black Ethiopians"; and Esposito, "Rubens's Encounter with Natural Philosophy and the 'Occult Sciences' in 17th-century Italy." See also Meganck, "The 'Reddener"” and "Rubens on the Human Figure: Theory, Practice and Metaphysics," in Rubens: A Genius at Work; The Works of Peter Paul Rubens in the Royal Museums of Fine Arts of Belgium Reconsidered, ed. Michel Draguet and Joost Vander Auwera, exh. cat. (Tielt: Lannoo, 2007), 52-64, esp. 57.

52. Meganck, “The 'Reddener,"' 149. On this image, see also Kristin Lohse Belkin, Copies and Adaptations from Renaissance and Later Artists, Corpus Rubenianum Ludwig Burchard XXVI, vol. 1 (2009), 234-38, no. 119; and Kirk Nickel, "Portrait of Paracelsus," in Early Rubens, 136-39. 
53. Meganck, “The 'Reddener,” 147; Smith, "Vermilion, Mercury, Blood, and Lizards.”

54. These sections were omitted in the $\mathbf{1 7 7 6}$ publication but can still be found in the eighteenthcentury copy of Rubens's notebook known as the Ganay manuscript; see Meganck, "The 'Reddener,"' 146. On the Paracelsan tria prima, see also Leonhard, Bildfelder, 264-270.

55. On Rubens's interest in the materia prima and its symbolic relationship to the color black, see Esposito, "Black Ethiopians."

56. Fludd's work is recorded in the nineteenth-century reconstruction of Rubens's library by Prosper Arents; see Alfons K. L. Thijs, ed., with contributions by Frans Baudouin, Lia Baudouin, Elly Cockx-Indestege, Jacques De Bie and Marcus de Schepper, Prosper Arents: De Bibliotheek van Pieter Paul Rubens: Een reconstructie (Antwerp: Vereniging der Antwerpse Bibliofielen, 2001), 345.

57. Etching in Robert Fludd, Utriusque cosmi maioris scilicet et minoris metaphysica, physica atque technica historia in duo volumina secundum cosmi differentiam divisa (Oppenheim, 1617), 1:37.

58. See Marjolein Leesberg and Huigen Leeflang, eds., Hendrick Goltzius, The New Hollstein Dutch and Flemish Etchings, Engravings and Woodcuts, 1450-1700 (Ouderkerk aan den Ijssel: Sound and Vision, 2012), 3:381.

59. Georges Didi-Huberman, trans. Jane Marie Todd, Fra Angelico: Dissemblance and Figuration (Chicago: University of Chicago Press, 1995), 9. The blood also resonates with Didi-Huberman's concept of a "patch," a site in which a painting seems to "proclaim itself as pure matter"; see Didi-Huberman, "The Art of Not Describing: Vermeer-the Detail and the Patch," History of the Human Sciences 2 (1989), 135. Much of the critical discourse surrounding disfiguration and materiality derives from the French critical term "macula"; see the journal of that name published in Paris in 1976-1978.

60. At the time of this publication, both versions of the painting are undergoing technical study at the University of Antwerp in conjunction with both the Kunsthistorisches Museum and the Moravian Gallery in Brno: AXES, "Rubens' Medusas: Find the Seven Differences," University of Antwerp website, accessed July 22, 2021, HTTPS://WWW.UANTWERPEN.BE/EN/RESEARCH-GROUPS/AXES/X-RAYSPECTROSCOPY-AND-IMAGING/RESEARCH-FUNDING/CHAIR-FOR-THEARTS/RESEARCH-ACTIVITIES/RUBENS-MEDUSA.

61. On cochineal, see Elena Philips, Cochineal Red: The Art History of a Color (New York: Metropolitan Museum of Art, 2010). Byron Ellsworth Hamann has argued that the reflected red curtain in Velázquez's Las Meninas (1656, Museo del Prado) refers to its material basis in cochineal and therefore also to the Atlantic world: "The Mirrors of Las Meninas: Cochineal, Silver, and Clay," Art Bulletin 92, nos. 1/2 (March-June 2010): 18-20. I thank Joanna Woodall for pointing out the potential significance of cochineal to Rubens and Snyders's Head of Medusa when she supervised my master's thesis at the Courtauld Institute in 2006.

62. On sixteenth-century Antwerp as a center of vermilion production, see Filip Vermeylen, "The Colour of Money: Dealing in Pigments in Sixteenth-Century Antwerp," in Trade in Artists' Materials: Markets and Commerce in Europe to 1700, ed. Jo Kirby, Susie Nash, and Joanna Cannon (London: Archetype, 2010), 356-65. 
63. On the methods of making vermilion, see Smith, "Vermilion, Mercury, Blood, and Lizards," 35-39.

64. Cennino Cennini, trans. Lara Broecke, Il Libro dell'Arte: A New English Translation and Commentary with Italian Transcription (London: Archetype, 2015), 64. On the blackening of Rubens's reds over time, see the technical study by Willemien Anaf, Koen Janssens, and Karolien De Wael, "Formation of Metallic Mercury during Photodegradation/Photodarkening of $\alpha-H g S:$ Electrochemical Evidence," Angewandte Chemie International Edition 52, no. 48 (2013): 12568-71.

65. The philosopher's stone was often described as a "red powder"; see Smith, "Vermilion, Mercury, Blood, and Lizards," 40. On red in alchemy and in seventeenth-century still-life painting, see also Leonhard, Bildfelder, 287-304.

66. Joachim von Sandrart, Teutsche Akademie (Frankfurt, 1675), 3:292. On this anecdote, which was repeated in Roger de Piles's Abrégé de la vie des peintres (Paris, 1699), 40, see Göttler, "Vulcan's Forge," 52-53.

67. Herman Van der Wee, The Growth of the Antwerp Market and the European Economy (The Hague: Martinus Nijhoff, 1963), 2:327, cited in Elizabeth Honig, Painting and the Market in Early Modern Antwerp (New Haven and London: Yale University Press, 1998), 6.

68. See the introduction to Christine Göttler, Bart Ramakers, and Joanna Woodall, eds., "Trading Values in Early Modern Antwerp," special issue, Nederlands Kunsthistorisch Jaarboeck 64 (2014): 9-37.

69. See Göttler, "Vulcan’s Forge.”

70. See the technical discussions in Tiarna Doherty, Mark Leonard, and Jørgen Wadum, "Brueghel and Rubens at Work: Technique and the Practice of Collaboration," in Rubens and Brueghel: A Working Friendship, ed. Anne T. Woollett and Ariane van Sucthelen, exh. cat. (Zwolle: Waanders, 2006), 215-51.

71. On this image, see Julius Held, "Prometheus Bound," Philadelphia Museum of Art Bulletin 59, no. 279 (August 1963): 16-32; Christopher D. M. Atkins, The Wrath of the Gods: Masterpieces by Rubens, Michelangelo, and Titian, exh. cat. (New Haven and London: Philadelphia Museum of Art in association with Yale University Press, 2015); Anne T. Woolett, "Prometheus Bound," in Rubens \& Brueghel: A Working Friendship, 166-73, cat. no. 221; and Fiske Kimball, "Rubens' Prometheus," Burlington Magazine 94, no. 588 (March 1952): 67-68. The attribution of the eagle in Prometheus Bound is confirmed by Rubens himself in a letter of 1608 to Sir Dudley Carleton; see Held, "Prometheus Bound," 19-20. Two versions of the work are extant today, one in the Philadelphia Museum of Art and the other in Landesmuseum in Oldenburg.

72. On the modes of viewing seventeenth-century Flemish collaborative painting, see Elizabeth Honig, "The Beholder as a Work of Art: A Study in the Location of Value in SeventeenthCentury Flemish Painting," Nederlands Kunsthistorisch Jaarboek 46 (1995): 252-97.

73. Since the attribution of the eagle to Snyders is firm, the close resemblance between the two paintings seems to strengthen the case for attributing the still life in Head of Medusa to Snyders as well.

74. See Aeschylus, trans. Janet Case, Prometheus Bound (London: Dent, 1905). Rubens would later depict Prometheus's theft of fire in a 1636 oil sketch for the Torre de la Parada cycle. 
75. Pomponio Gaurico, De Scultura, trans. Heinrich Brockhaus (Leipzig: F.A. Brockhaus, 1886), 164; and Natale Conti, Mythologiae (Paris, 1583) 4, ch. 6: "Prometheus is supposed to have been the first one to shape men out of mud." A Prometheus Bound by Jacob Jordaens (Wallraf-Richartz-Museum, Cologne) depicts a small marble bust on the mountainside; Held, "Prometheus Bound," 31.

76. Caroline Van Eck, "Gemankeerde Pygmalions en successvolle Medusa's," in Levende Beelden: Kunst werken en kijken (Leiden and Brussels: Leiden University Press, 2011), 8-27 and 108-109, quote on 10. See also Caroline van Eck, "The Petrifying Gaze of Medusa: Ambivalence, Explexis, and the Sublime," Journal of Historians of Netherlandish Art 8, no. 2 (Summer 2016), HTTPS://DOI.ORG/10.5092/JHNA.2016.8.2.3. Van Eck draws from the discussion of ikonopoesis in the Medusa myth by Françoise Frontisi-Dutroux, "La Gorgone, paradigme de creation d'images," in Les Cahiers du Collège Iconique: Communications et Débats (Paris: La Diffusion Française, 1993); English translation in The Medusa Reader, 262-67.

77. Olga Raggio, “The Myth of Prometheus: Its Survival and Metamorphoses up to the Eighteenth Century," Journal of the Warburg and Courtauld Institutes 21, nos. 1/2 (1958): 44-62. Baudius's reference to Prometheus's "ever-regrowing" liver recalls similar descriptions, found in accounts of the myth of Tityus (especially Virgil's Aeneid 6.595-600) of Tityus's liver "inexhaustible" or "ever-renewing." The myth of Prometheus was closely linked in the Renaissance to that of Tityus, who was punished by Zeus by having two vultures tear out his liver; Held, "Prometheus Bound," 26.

78. Baudius, a professor at the University of Leiden, knew both Rubens and his brother Philip.

79. I follow the translation given in Kimball, "Rubens' Prometheus," 67.

80. As Christine Göttler ("The Alchemist, the Painter, and the 'Indian Bird") has argued, fire was invoked by Flemish Baroque painters to symbolize their own transformative power over the natural world.

81. I thank Joris van Gastel, Giannis Hadjinicolau, and Markus Rath for allowing me to present these thoughts on Head of Medusa and Prometheus Bound at their session "Productive Paragones" at the Renaissance Society of America annual meeting, Berlin, 2015.

82. On the various (lost and extant) studies and versions of Rubens's The Finding of Erichthonius, see Fiona Healy's entries in Rubens Mythological Subjects: Achilles to the Graces (Corpus Rubenianum Ludwig Burchard, XI, vol. 1), ed. Elizabeth McGrath with Bert Schepers (London and Turnhout: Harvey Miller, 2016), 393-434, cat. 40-42b. See also Aneta Georgievska-Shine, Rubens and the Archaeology of Myth, 1610-1620: Visual and Poetic Memory (Surrey: Ashgate, 2009), 153-85; and "From Ovid's Cecrops to Rubens's City of God in The Finding of Erichthonius," Art Bulletin 86, no. 1 (March 2004): 58-74. See also Eveliina Juntunen, Peter Paul Rubens' bildimplizite Kunsttheorie in ausgewählten mythologischen Historien 1611-1618 (Petersberg: Michael Imhof, 2005), 84-99; and Svetlana Alpers, "Manner and Meaning in Some Rubens Mythologies," Journal of the Warburg and Courtauld Institutes 30 (1967): 272-95. See also Wolfgang Stechow, "The Finding of Erichthonius: An Ancient Theme in Baroque Art," in Latin American Art, and the Baroque Period in Europe, Studies in Western Art 3 (Princeton: Princeton University Press, 1963): 27-35. Rubens often recast ancient myths as allegories of nature's fertility, a 
tendency Elizabeth McGrath ("Garlanding the Great Mother") has attributed to his antiquarian interest in iconographies of nature that peaked in the 1610s.

83. The story is recounted twice in Ovid, first in its tragic denouement (Metamorphoses 2:53165): a crow reports Aglaurus's disobedience to Minerva, who punishes her by driving her mad until she falls off a cliff to her death. Later (Metamorphoses 2:708-832), an earlier segment is narrated: Mercury falls in love with Herse, but when Aglaurus, jealous of her sister, refuses to let him past the threshold, the god turns her to stone.

84. On this statue and its early modern reception, see Andrea Goesch, Diana Ephesia: Ikonographische Studien zur Allegorie der Natur in der Kunst vom 16.-19. Jahrhundert (Frankfurt and New York: Lang, 1996); and Zorach, "Milk," in Blood, Milk, Ink, Gold, 82-134.

85. Georgievska-Shine, “From Ovid's Cecrops to Rubens's City of God," 58; and Alpers, "Manner and Meaning," 373.

86. On the large canvas in the Liechtenstein Museum, see Fiona Healy, "The Discovery of Erichthonius by the Daughters of Cecrops: Painting," in Rubens Mythological Subjects, 40214, no. 41. See also Johann Kräftner, Wilfred Sepel, and Renate Trnek, eds., Peter Paul Rubens: The Masterpieces from the Viennese Collections (Vienna: Christian Brandstätter, 2004), no. 29, 131. On the Courtauld oil sketch, see Held, Oil Sketches, no. 231, 2:318-19; and Michael Jaffé, Rubens, Catalogo Completo (Milan: Rizzoli, 1989), no. 319, 208. A severely reduced fragment now in the Allen Art Museum at Oberlin College is thought to be from a later version Rubens created in the 1630s; see Ludwig Burchard, "Rubens's Daughters of Cecrops," Allen Memorial Art Museum Bulletin 1 (1953): 4-26. On Van Stompel's print, a sheet of which is held in the National Gallery in Washington (1975.23.54), see Juntunen, Peter Paul Rubens' bildimplizite Kunsttheorie, 90-91.

87. Alpers ultimately used the image to explore "the problem of the relationship between allegorical meaning and dramatic action"; "Manner and Meaning," 292. Held disagreed with Alpers's purely allegorical interpretation, interpreting the work instead as a synthesis of both Ovidian versions of the myth.

88. Alpers, "Manner and Meaning," 283.

89. In particular, the fountain of Diana Ephesus created by Pirro Ligorio (ca. 1500-1589) for the Villa d'Este in Tivoli, Lazio. On the sculptural precedents for Rubens's depiction of Diana Ephesus, see Juntunen, Peter Paul Rubens' bildimplizite Kunsttheorie, 95-96. On the Tivoli fountain, see also Zorach, Blood, Milk, Ink, Gold, 99.

90. Roger de Piles, who owned a copy of the notebook in the late seventeenth century, reproduced this text in his Cours de peinture (Paris, 1708), 139-41. The De imitation statuarum has been explored in depth by Andreas Thielemann; see his "Rubens' Traktat De imitatione statuarum," in Ursula Rombach and Peter Seiler, eds., Imitatio als Transformation: Theorie und Praxis der Antikennachahmung in der Frühen Neuzeit (Petersberg: Michael Imhof, 2012), 95-150; and his "Peter Paul Rubens (15771640), De imitatione statuarum," in Manfred Luchterhandt et al., eds., Abgekupfert: Roms Antiken in den Reproduktionsmedien der Frühen Neuzeit; Katalog zur Aussellung Kunstsammlung der Gipsabgüsse, exh. cat. (Petersberg: Michael Imhof, 2014), 319-21. See also Steven J. Cody, "Rubens and the 'Smell of Stone': The Translation of the Antique and the Emulation of Michelangelo," Arion: A Journal of Humanities and the Classics 20, no. 3 
(Winter 2013): 39-55. Rubens's views on the reanimation of ancient sculpture in the De imitatione statuarum have been linked to his Death of Seneca (1615) by Heinen ("Haut und Knochen"). On The Discovery of Erichthonius as a visual expression of the ideas found in the De imitation statuarum, see Juntunen, Peter Paul Rubens' bildimplizite Kunsttheorie, 99.

91. De Piles, Cours de Peinture, 139.

92. De Piles, Cours de Peinture, 139-40.

93. Another visual expression of this idea is the overturned urn held parallel to the picture plane by a river god, a recurrent theme in Rubens's works.

94. On Rubens's Deucalion and Pyrrha, see Georgievska-Shine and Silver, Rubens, Velázquez, and the King of Spain, 33-35; Held, Oil Sketches, cat. no. 184, 1:270-71; and Alpers, Torre de la Parada, 22. No large canvas painting after Rubens's model survives.

95. Ovid, Metamorphoses, 1:313-415.

96. Alpers, Torre de la Parada, 188-89.

97. Ovid, Metamorphoses 3:94-115. The large canvas of Cadmus Sewing the Dragon's Teeth was executed by Jacob Jordaens and is in the Prado (inv. no. 1713). On the oil sketch, see Held, Oil Sketches, cat. no. 176, 1:264-65.

98. I take this phrase from the English translation of Horst Bredekamp, The Lure of Antiquity and the Cult of the Machine: The Kunstkammer and the Evolution of Nature, Art, and Technology, trans. Allison Brown (Princeton: Markus Wiener Publishers, 1995), 47.

99. See the classic study by Jurgis Baltrusaitis, trans. Richard Miller, Aberrations: An Essay on the Legend of Forms (Cambridge, MA, and London: MIT Press, 1989). On "pictorial stones," see also Fabio Berry, “Painting in Stone': Early Modern Experiments in a Metamedium," Art Bulletin 99, no. 3 (July 2017): 30-61. On "nature as an artist," see also Lorraine Daston and Katherine Park, Wonders and the Order of Nature (New York: Zone Books, 2001), 255-301.

100. On this passage in Alberti, see Roland Kanz, Die Kunst des Capriccio: Kreativer Eigensinn in Renaissance und Barock (Munich: Deutscher Kunstverlag, 2002), 77.

101. 101. Leon Battista Alberti, On Painting, trans. Cecil Grayson (London: Penguin Classics, 1991), 60.

102. H. W. Janson, "The 'Image Made by Chance' in Renaissance Thought," in De artibus opuscula XL: Essays in Honor of Erwin Panofsky, ed. Millard Meiss (New York: New York University Press, 1961), 54-66. Primary sources discussed by Janson include Lucretus, Philostratus, Albertus Magnus, Leonardo, and Vasari. On the "image made by chance" in later seventeenth-century Dutch landscape painting and art theory, with reference to spontaneous generation, see Leonhard, Bildfelder, 85-88.

103. Harvard Art Museums, 1942.174. Also known as Quos ego, after the passage in Virgil's Aeneid on which it is based, this oil study was a model for the Pompa introitus Ferdinandi, a triumphal procession designed by Rubens and held in Antwerp in 1635. See Anna C. Knaap and Michael C. J. Putnam, eds., Art, Music, and Spectacle in the Age of Rubens: The Pompa Introitus Ferdinandi (London and Turnhout: Brepols, 2013). On the technical fluency of the Quos ego oil sketch, see Jakob Rosenberg, "Rubens's Sketch for The Wrath of Neptune," Bulletin of the Fogg Museum of Art 10, no. 1 (November 1942): 10-11.

104. On Rubens's previous depictions of Eve, see Jeremy Wood, "Adam and Eve: Painting after Titian," in Rubens: Copies and Adaptations from Renaissance and Later Masters: Italian 
Artists. 2, Titian and North Italian Art (London: Harvey Miller, 2010), Corpus Rubenianum Ludwig Burchard 26, cat. no. 111, 1:111-19; and Ariane van Suchtelen, "The Garden of Eden with the Fall of Man," in Rubens and Brueghel: A Working Friendship, cat. no. 4, 6465. The woman's long blonde hair also recalls Rubens's painting of Venus at a Mirror (ca. 1615).

105. Held, Oil Sketches, 1:271. The female figure's hand, whose placement is modeled on the Venus pudica statue, disappears autoerotically behind her upper thigh.

106. Rubens frequently drew inspiration from illustrated Ovids, including the edition published by the Plantijn Press in Antwerp in 1591; Held, Oil Sketches, 1:281. As Elizabeth McGrath notes: "These works often specifically advertised themselves as aimed at artists"; "Rubens and Ovid," in The Afterlife of Ovid, ed. Peter Mack and John North (London: Institute of Classical Studies 2015), 159.

107. I thank Anna Knaap for pointing out this stylistic contrast when I presented these thoughts on Rubens's Deucalion and Pyrrha at the Renaissance Society of America annual meeting, Boston, 2016.

108. Wood, Rubens: Copies and Adaptations, 111-19. Both Titian's Fall of Man (ca. 1550) and Rubens's copy after it (1628-1629) are now in the Prado. On Rubens and Titian, see Hilliard Goldfarb, David Freedberg, and Manuela B. Mena Marqués, Titian and Rubens: Power, Politics and Style (Boston: Isabella Stewart Gardner Museum, 1998), especially Freedberg's essay "Rubens and Titian: Art and Politics," 30-60. See also Aneta GeorgievskaShine, "Rubens's Europa and Titian's Auctoris Index," Nederlands Kunsthistorisch Jaarboek 59, no. 1 (2009): 274-91.

109. Rebecca Zorach drew my attention to the potential racial implications of Rubens's sketch and its conception of the human when I presented a paper ("Mythologizing Matter: Rubens's Images of Spontaneous Generation") at the workshop organized by Claudia Swan, "Shaped by Nature, Forged by Art: Early Modern Objects and Images" (Northwestern University, May 20-21, 2016). I also thank Shawon Kinew for encouraging me to acknowledge the colonial aspects of the image in relation to its ultimate Spanish audience, and Claudia Swan for pointing me toward the Stradanus print.

110. On Theodoor de Bry's engravings as expressions of the amorphousness of the "new world" and its inhabitants, see Michael Gaudio, "Making Sense of Smoke: Engraving and Ornament in de Bry's America," in Engraving the Savage: The New World and Techniques of Civilization (Minneapolis and London: University of Minnesota Press, 2008), 45-85.

111. Marjolein Leesberg and Huigen Leeflang, eds., Stradanus, The New Hollstein Dutch and Flemish Etchings, Engravings and Woodcuts, 1450-1700 (Ouderkerk aan den Ijssel: Sound and Vision, 2008), 3:323. On the print within the Nova Reperta series, see Dániel Margócsy, "Stradanus: Nova Reperta," in Prints and the Pursuit of Knowledge in Early Modern Europe, ed. Susan Dackerman (New Haven: Yale University Press, 2011), cat. no. 1, 38-45. The original drawing by Stradanus is in the Metropolitan Museum of Art, 1974.205.

112. Americen Americus retexit, \& Semel vocauit inde semper exitam.

113. Rubens owned both de Acosta's and de Bry's treatises and used them as sources for his allegorical image of Mount Potosi in the Pompa introitus Ferdinandi (1633-4); Elizabeth McGrath, "Rubens's Arch of the Mint," Journal of the Warburg and Courtauld Institutes 37 (1974): 196. 
114. José de Acosta, Historia natural y moral de las Indias (Seville, 1590), book 1, chapters 25, 82. Translation adapted from the English edition (London, 1609) by Edward Grimson, ed. Clements R. Markham (London: Hakluyt Society, 1880), 70-71.

115. De Acosta, Historia natural y moral, 71.

116. For a study of shifting conceptions of the human in early modern Europe in relation to illustrated maps, see Surekha Davies, Renaissance Ethnography and the Invention of the Human: New Worlds, Maps, and Monsters (Cambridge: Cambridge University Press, 2016). By Rubens's time, there was already a history of familiarizing newly encountered peoples to European audiences by rendering them as standard image types, including Adam and Eve. Hans Burgkmair the Elder's 1508 woodcut In Allago (In Algoa) is an example. See Marisa Mandabach, "Burgkmair and Glockendon: Peoples of Africa and India," in Prints and the Pursuit of Knowledge, 326-31, cat. 79 (326).

117. On race in Rubens and in the historiography on Rubens, see Shawon Kinew, "Sedlmayr's Mother-of-Pearl: Further Notes on Rubens and Flesh Color," Selva: A Journal of the History of Art, 2 (Fall 2020): 88-96.

118. For Roger de Piles, tonal modeling was an intrinsic part of Rubens's colorisme; Svetlana Alpers, The Making of Rubens (New Haven: Yale University Press, 1995), 75. The association of Rubens's art with "coloring" as opposed to "design" was first made by Bellori, then picked up by de Piles.

119. On the relationship between artisanal and natural knowledge in early modern Europe, see Pamela Smith, The Body of the Artisan: Art and Experience in the Scientific

Revolution (Chicago and London: University of Chicago Press, 2004); and Dupré and Göttler, Knowledge and Discernment. On how paintings by Rubens and Van Dyck informed seventeenth-century theories of color and optics, see Leonhard, "The various natures of middling colours."

120. On the technical "fluency" of Rubens's oil sketches, see David Freedberg, "The Hand of Rubens," in Peter Paul Rubens: Paintings and Oil Sketches, exh. cat. (New York: Gagosian Gallery, 1995), 8. On speed as a technical and aesthetic quality in Venetian painting and art criticism, see Una Roman d'Elia, "Tintoretto, Aretino, and the Speed of Creation," Word \& Image 20 (2004): 206-18.

121. Van Hout and Balis, Rubens Unveiled, 55-57.

122. British Library, MS 2052. On the Mayerne manuscript, see especially Jenny Boulboullé, "Drawn up by a learned physician from the mouths of artisans: The Mayerne manuscript revisited," Nederlands Kunsthistorisch Jaarboek 68, no. 1 (2019): 227-29.

123. On the Rubens note in the Mayerne manuscript, the relationship between Rubens's technique of alternatively condensing and thinning colors, and Paracelsan ideas about modifying the elements, see Heinen, "Haut und Knochen," 81-82; and Leonhard, "The Various Natures of Middling Colours," 168. The transcription of Rubens's theoretical notebook, most likely made by Van Dyck, includes a recipe for a varnish made with turpentine; Meganck, "The 'Reddener," 147.

124. British Library, MS 2052, fol. 9v. I follow the translation in Jenny Boulboullé, "Drawn up by a learned physician," 227.

125. Heinen, "Haut und Knochen"; Thielemann, "Rubens' Traktat De Imitatione statuarum," 113; Kinew, "Sedlmayr's Mother-of-Pearl," 94. 
126. On Rubens's grounds, see Van Hout and Balis, Rubens Unveiled, 38-51; on the doodverf in Rubens, 60-64. On Rubens's uses of the doodverf, see also Van Hout, "Functies van doodverf met bijzondere aandacht voor de onderschildering en andere onderliggende Stadia in het Werk van P.P. Rubens" (PhD diss., Katholieke Universiteit, Leuven, 2005); and "Meaning and Development of the Ground Layer in Seventeenth-Century Painting," Leids kunsthistorisch jaarboek 11 (1998): 199-225. On the longer history of the doodverf in Netherlandish painting, see Hessel Miedema, "Over kwaliteitsvoorschriften in het St. Lucasgilde, over 'doodverf,"” Oud Holland 101 (1987): 141-47. For comparison, on Rembrandt's use of the doodverf, see Nicola Suthor, “Transparenz der Mittel: Zur Sichtbarkeit der Imprimatur in einigen Werken Rembrandts," in Gottfried Böhm, ed., Der Grund: Das Feld des Sichtbaren (Munich: Fink, 2012), 223-50.

127. In Genesis 2:7 God is described as creating Adam from the "dust of the earth."

128. Giorgio Vasari, Le Vite de' piu eccellenti pittori, scultori, et architettori (Florence, 1568), 12: "Cosi dunque il primo modello, onde usci la prima imagine dell'huomo fu una massa di terra; et non senza cagione: percioche il divino Architetto del tempo, et della natura, come perfetissimo volle mostrare nella imperfezzione della materia, la via, del levare, et dell'aggiugnere; nel medesimo modo, che sogliono fare i buoni scultori; et pittori, i quali ne' lor modelli, aggiungendo, et levando, riducono le imperfette bozze a quel fine, et perfezzione che vogliono. Diedegli colore vivacissimo di carne, dove s'è tratto nelle pitture poi da le Miniere della terra gli istessi colori, per contraffare tutte le cose, che accaggiono nelle Pitture." Translation adapted from Giorgio Vasari, The Lives of the Most Eminent Painters, Sculptors, and Architectsi, trans. Gaston du C. De Vere (London: Macmillan and Co. Ld. \& The Medici Society), 1912-14: xxxvii-viii.

129. On the engraved vignettes and title page Rubens created for Aguilonius's Opticorum libri sex (1613), see Julius Held, "Rubens and Aguilonius: New Points of Contact," Art Bulletin 61, no. 2 (June 1979): 257-64; Michael Jaffé, "Rubens and Optics: Some Fresh Evidence," Journal of the Warburg and Courtauld Institutes 34 (1971): 362-66; and Charles Parkhurst, “Aguilonius' Optics and Rubens' Color,” Nederlands Kunsthistorisch Jaarboek 12 (1961): 35-48.

130. On ancient and early modern analogies between colors and the elements, see Leonhard, Bildfelder, 343-45; and Fehrenbach, "Calor nativus - color vitale," 158-60.

131. On this etching, see Michael Gaudio, “The Emblem in the Landscape: Matthäus Merian's Etchings for Atalanta fugiens," in Furnace and Fugue: A Digital Edition of Michael Maier's "Atalanta fugiens" (1618) with Scholarly Commentary, digital edition (Charlottesville: University of Virginia Press, 2020), HTTPS://FURNACEANDFUGUE.ORG/ESSAYS/GAUDIO.

132. Gaudio, "The Emblem in the Landscape."

133. Rubens's oil sketches had a practical and utilitarian function within his workshop, and the question remains as to what extent Rubens would have understood them as works of art in their own right; see Van Hout and Balis, Rubens Unveiled, 17. However, Rubens may well have discussed his oil sketches with learned friends, associates, connoisseurs, and other artists on both a theoretical and technical level. On early modern artist workshops in the Low Countries as spaces of exchange between artisanal and scholarly knowledge, see Dupré and Göttler, introduction to Knowledge and Discernment; on artist workshops in the Low 
Countries as "arenas in which the learned taught the skilled, and the skilled taught the learned," see Pamela Long, Artisan/Practitioners and the Rise of the New Sciences, 14001600 (Corvallis, OR: Oregon State University Press, 2011), 95. On the series of the Four Elements and Five Senses by Rubens and Bruegel-and painters' workshops in early seventeenth-century Antwerp as "laboratories of invention and experimentation" in which "the more traditional mode of acquiring knowledge through books" existed side-by-side with both the "observation of nature" and artisanal labor-see Göttler, Ramakers, and Woodall, introduction to "Trading Values in Early Modern Antwerp," 25.

134. An allusion to Rubens's first name has been discerned in the self-portrait now in the Windsor collection; Shawe-Taylor and Scott, Rubens to Brueghel, 143.

135. Svetlana Alpers, The Art of Describing: Dutch Art in the Seventeenth Century (Chicago: University of Chicago Press, 1983), 5. For this letter, see Charles Ruelens and Max Rooses, Correspondance de Rubens et documents epistolaires concernant sa vie et ses oeuvres, 6 vols. (Antwerp: Veuve de Backer, 1887-1909), 5:153. For an English translation, see Ruth Magurn, The Letters of Peter Paul Rubens (Cambridge, MA: Harvard University Press, 1955), 322-23.

136. Alpers, Art of Describing, 5. 